John Haldon, Arlen F. Chase, Warren Eastwood, Martin Medina-Elizalde, Adam Izdebski, Francis Ludlow, Guy Middleton, Lee Mordechai, Jason Nesbitt, B.L. Turner II

\title{
Demystifying Collapse: Climate, environment, and social agency in pre-modern societies
}

\begin{abstract}
Collapse is a term that has attracted much attention in social science literature in recent years, but there remain substantial areas of disagreement about how it should be understood in historical contexts. More specifically, the use of the term collapse often merely serves to dramatize long-past events, to push human actors into the background, and to mystify the past intellectually. At the same time, since human societies are complex systems, the alternative involves grasping the challenges that a holistic analysis presents, taking account of the many different levels and paces at which societies function, and developing appropriate methods that help to integrate science and history. Often neglected elements in considerations of collapse are the perceptions and beliefs of a historical society and how a given society deals with change; an important facet of this, almost entirely ignored in the discussion, is the understanding of time held by the individuals and social groups affected by change; and from this perspective 'collapse' depends very much on perception, including the perceptions of the modern commentator. With this in mind, this article challenges simplistic notions of 'collapse' in an effort to encourage a more nuanced understanding of the impact and process of both social and environmental change on past human societies.
\end{abstract}

There are substantial disagreements about how the term 'collapse' should be understood and used in historical and other contexts, the more so since questions of scale and chronology, which lie at the heart of the matter, are rarely paid more than token attention. The use of 'collapse' often dramatizes long-past events, ignores human agency, and even serves to mystify and 'orientalize' the past intellectually. Tales of

This article is one outcome of a Princeton University Climate Change and History Research Initiative colloquium held in May 2017. Francis Ludlow acknowledges support from an Irish Research Council Starting Laureate Award for the Climates of Conflict in Ancient Babylonia (CLICAB) project (IRCLA/ 2017/303), as well as the Irish Research Council 'Irish Droughts: Environmental \& Cultural Memories' project (COALESCE/2019/43).

John Haldon, Princeton University; Arlen F. Chase, Pomona College; Warren Eastwood, University of Birmingham; Martin Medina-Elizalde, Auburn University; Adam Izdebski, Max-Planck Institute for the Science of Human History, Jena; Francis Ludlow, Trinity College Dublin; Guy Middleton, Charles University, Prague; Lee Mordechai, Hebrew University of Jerusalem; Jason Nesbitt, Tulane University; B.L. Turner II, Arizona State University

Ә Open Access. (C) 2020 John Haldon, published by De Gruyter. (cc) BY-NC-ND This work is licensed under the Creative Commons Attribution-NonCommercial-NoDerivatives 4.0 License.

https://doi.org/10.1515/mill-2020-0002 
mysterious and abrupt collapse have both romantic and tragic appeal as well as serving to generate catchy parables for our own times, especially when our contemporary relationship with the natural environment is so fraught with concern. ${ }^{1}$ It is often also the case that older ideas and interpretations are accepted as simple truths by nonarchaeologists and non-historians unfamiliar with the results of more recent specialist research, partly because such ideas have become myths or memes that have taken on a life of their own. Additionally, the views of some specialists can become privileged and accorded the status of 'facts', especially by those outside the academic context, rather than being regarded as hypotheses that must be subject to ongoing critique or as narratives that are open to serious questioning.

Just as it is important for archaeologists and historians to engage with palaeoclimatic data and to participate in interdisciplinary projects, it also is vital for non-historians/archaeologists to engage seriously with the ever-changing historical and archaeological literature and to understand the provisional nature of historical and archaeological reconstructions and hypotheses of causality. In recent academic and public discourse 'collapse' is often deployed in contrast to 'sustainability', as though these are the only options, thus overly simplifying much more complex relationships and developments observed historically. ${ }^{2}$ This simplification also has negative impacts on current debates about future planning and the potential for contemporary societal and political systems to respond to the challenges presented by global climate and environmental change.

This is not the place to review the extensive literature on how to define and deploy 'collapse' in social science literature. Like others before us, ${ }^{3}$ we argue here that the application of the concept as an historiographical tool needs to be done with greater nuance and less casually than is generally the case. The work of historians is frequently deployed by others - comparative social scientists, climate and environ-

1 G.D. Middleton, Understanding collapse: ancient history and modern myths (Cambridge 2017), 5-10. 2 Middleton, Understanding collapse, offers a number of examples.

3 See, for example: K.W. Butzer 'Collapse, environment and society', Proceedings of the National Academy of Sciences of the USA 109 (2012), 3632-3639; K.W. Butzer and G.H. Endfield, 'Critical perspectives on historical collapse', Proceedings of the National Academy of Sciences of the USA 109 (2012), 3628-3631 summarize the issues; P.R. Williams, 'Rethinking disaster-induced collapse in the demise of the Andean highland states: Wari and Tiwanaku', World Archaeology 33 (2002), 361374; P.A. McAnany and N. Yoffee, Questioning collapse: human resilience, ecological vulnerability and the aftermath of empire (Cambridge 2009); G. Middleton, 'Nothing lasts forever: environmental discourses on the causes of past societal collapse', Journal of Archaeological Research 20/3 (2012), 257-307; S. Johnson, Why did ancient civilizations fail? (New York 2017); R. Storey and G.R. Storey, Rome and the Classic Maya: comparing the slow collapse of civilizations (New York 2017); G. Middleton, Understanding collapse: ancient history and modern myths (Cambridge 2017); T. Cunningham and J. Driessen, Crisis to collapse: the archaeology of social breakdown (Aegis 11. Louvain 2017); R.K. Faulseit, Beyond collapse: archaeological perspectives on resilience, revitalization, and transformation in complex societies (Carbondale 2016); also the essays in G.M. Schwartz and J.J. Nichols, eds., After collapse: the regeneration of complex societies (Tucson 2006). For a broad summary of the debate: G. Middleton, Understanding collapse (n. 1 above). 
mental historians, and those working on sustainability scenarios and future planning to illustrate their own particular arguments - sometimes with misleading results where the complexities of the historical processes and their outcomes are not made sufficiently clear to those outside the discipline. ${ }^{4}$ And there are indications in the recent literature that crude 'collapsist' descriptions of past historical events or sets of events have had unfortunate effects on contemporary debates about sustainable responses to current or predicted future challenges. While there is room for the concept of collapse to evolve, historians and archaeologists must in general be much more precise about how they use it. ${ }^{5}$

\section{Discrepant temporalities: time and human agency}

Temporality - 'time awareness' - and chronology represent one aspect that has been almost entirely ignored in discussions about collapse. There are two aspects to this: first, that of the temporality of the historical culture as well as the modern commentator; and, second, the extended, multi-level and regionally differentiated nature of the various historically-located processes of transformation lumped together under the rubric of 'collapse'. The second of these aspects will be addressed below; the first concerns not only the absolute length of time taken in the past for certain processes to occur, but also the perception of time of the individuals and social groups affected by or involved in such changes. Just as importantly are the ways in which our own approach to past time affects our analyses and interpretations and the assumptions we then make about the effects of change and their impact on past cultures and civilisations. Describing what appear from our perspective as dramatic changes under the rubric of 'collapse' can do a substantial injustice both to the proc-

\footnotetext{
4 This becomes the more pressing as such cross-disciplinary studies increase in number, coverage and approach: see the survey in J.G. Manning and D. Hoyer, 'Empirical regularities across time, space and culture: a critical review of comparative methods in ancient historical research', Historia 67 (2018), 169-190. Useful critical comments also in A. Hornborg, 'Perspectives on Diamond's Collapse: how societies choose to fail or succeed', Current Anthropology 46 (2005) (supplement), S94S95 (other critical discussion on this topic can be found in the same issue). For similar and comparative concerns, see the essays in N. Yoffee, ed., The Evolution of Fragility: Setting the Terms (Cambridge 2019).

5 See in particular S. Strunz, M. Marselle and M. Schröter, "Leaving the "sustainability or collapse" narrative behind', Sustainability Science 14 (2019), 1717-1728 https://doi.org/10.1007/s11625-01900673-0. For recent work in the field of ecology and evolution, outlining a unified socio-ecological framework within which to understand, define and quantify collapse, see G.S. Cumming and G.D. Peterson, 'Unifying research on social-ecological resilience and collapse', Trends in Ecology and Evolution 32 (9) (2017), 695-713. On the historical-archaeological side, see S. Johnson, Why did ancient civilizations fail? (New York 2017); G. Middleton, Understanding collapse: ancient history and modern myths (Cambridge 2017); T. Cunningham and J. Driessen, Crisis to collapse: the archaeology of social breakdown (Aegis 11. Louvain 2017); R.K. Faulseit, Beyond collapse: archaeological perspectives on resilience, revitalization, and transformation in complex societies (Carbondale 2016).
} 
esses that took place in terms of the ways a society dealt with, became aware of, or reacted to change. The physical impact of changing environmental circumstances or sudden catastrophes, as well as perceptions of such events, upon the 'cultural logic' of a society is a key element: how people understand what happens in their world directly determines how they respond, as individuals as well as in groups. ${ }^{6}$ This surely has important implications not only for how we understand the past, but crucially for how we think contemporary societies might respond to comparable challenges. Yet the fact that a word such as 'collapse' depends for its value and meaning very much on both the perceptions of the modern commentator as well as the people we study receives virtually no attention.

\section{Time}

It is perhaps unsurprising that the vocabulary of collapse is most prominent in the literature encompassing climate and environmental impacts on society, simply because the chronological distances from the present involved in such studies are often very great. This permits an unconscious slippage whereby many lifetimes of human experience and cultural practice are compressed into a few sentences. Human actions need to be understood in terms of their 'timescape', the ways in which social praxis and perceptions are embedded within a context of continuing social processes functioning at a variety of temporal and spatial scales. While this is an observation made in the context of present-day perceptions of climate change and the environmental impact of human actions, it is equally valid when looking at the ways in which modern-day observers perceive the past. ${ }^{7}$ Perceptions of time are socially constructed. ${ }^{8}$ Just as people today are rarely able to think about the fu-

6 J. Haldon, L. Mordechai, T. Newfield, A.F. Chase, A. Izdebski, P. Guzowski, I. Labuhn and C.N. Roberts, 'History meets palaeoscience. Consilience and collaboration in studying past societal responses to environmental change', Proc. National Acad. of Sciences of the USA 115/13 (2018), 3210-3218 https://doi.org/10.1073/pnas.1716912115; K.W. Butzer 'Collapse, environment and society', Proceedings of the National Academy of Science 109 (2012), 3632-3639; K.W. Butzer and G.H. Endfield, 'Critical perspectives on historical collapse', Proceedings of the National Academy of Sciences 109 (2012), 3628-3631 summarize the issues; and see the contributions to R.J. McIntosh, J.A. Tainter and S. Keech McIntosh, eds., The way the wind blows: climate, history, and human action (New York 2000). Note also B. Ward-Perkins, The fall of Rome and the end of civilisation (Oxford 2005), 4-5 on the value-laden nature of the terms we may choose to impose on past people's experience.

7 S. Pahl, S. Sheppard, C. Boomsma and C. Groves, 'Perceptions of time in relation to climate change', WIREs Climate Change 5 (2014), 375-388.

8 See A. Gell, The anthropology of time: cultural constructions of temporal maps and images (Oxford 1992); N.D. Munn, 'The cultural anthropology of time: a critical essay', Annual Review of Anthropology 21 (1992), 93-123; S.J. Gould, Time's arrow, time's cycle (Cambridge, MA 1987); with regard to the construction of 'historical' time C.Y. Shanks and M. Tilley, Reconstructing archaeology-theory and practice (London 1992), esp. 135-136; and see also the helpful critical observations in T. Ingold, 'The temporality of the landscape', World Archaeology, 25/2 (1993), 59-76. 
ture meaningfully beyond a period of a few years or to grasp even the recent past in terms of human lifespan experience beyond a century at the most, so it is clear that scientists and scholars who are concerned with the longer-term past struggle not to conflate substantial numbers of lifetimes into experiential blips. ${ }^{9}$ As Wallerstein and Braudel have pointed out, we tend unconsciously to privilege time (distance to the past) over duration (distance within the past), ${ }^{10}$ in spite of ongoing discussion about the questions arising from modern concepts of time and attitudes to past societal experience. ${ }^{11}$ Recent work on 'trauma culture' and on the ways in which human agents in contemporary or near-contemporary cultures respond to events suggests that most people cannot recognize a 'collapse' when they are inside it and that such developments are generally defined as such only after they have taken place. It is therefore crucial to consider the perceptions of those who experienced the historical changes we are studying when we conceptualize broader historical events and narratives. $^{12}$

Historians and archaeologists with only very limited, or no, written archives at their disposal have come to rely increasingly on the new methodologies from the palaeosciences. But the chronological resolution and scale of the evidence offered by these disciplines is often far too coarse for the construction of a more refined historical account of societal change. ${ }^{13}$ The result has generally been that the historical human - timescale fades into the background; the archaeological timescale becomes generalized to approach and conform with the coarser chronologies of the palaeosciences; and the result is a dramatic compression of complex historical processes under an all-embracing single rubric - in this case, that of 'collapse'. The more distant the events being described, and the less qualitative the 'historical' data at our

9 B. Adam, Timewatch: the social analysis of time (Cambridge 1995); idem, Timescapes of modernity: the environment and invisible hazards (London/New York 1998), esp. 256; G. Benford, Deep time: how humanity communicates across millennia (New York 2001).

10 I. Wallerstein, 'Time and duration: the unexcluded middle. Reflections on Braudel and Prigogine', Thesis Eleven 54 (1998), 79-87; see also C. Gosden, Social being and time: an archaeological perspective (Oxford 1994).

11 See, for example, R. Bradley, 'Ritual, time and history', World Archaeology 23 (1991), 209-219. 12 For discussion of a specific historical culture in this respect: P. Odorico, 'Le temps de l'empire', in E.G. Saranti, Ai. Dellaporta and Th. Kollyropoulou, eds., Opseis tou Vyzantinou Chronou (Athens 2018), 30-41. On 'trauma culture': E.A. Kaplan, Trauma culture: the politics of terror and loss in media and literature (New Brunswick 2005); C. Caruth, Unclaimed experience: trauma, narrative and history (Baltimore 1996); W. Sewell, 'Historical events as transformations of structures: inventing revolution at the Bastille', Theory and Society 25/6 (1996), 841-881; P. Fussell, The Great War and modern memory (New York and London 1975).

13 In general: A. Izdebski et al., 'Realising consilience: How better communication between archaeologists, historians and natural scientists can transform the study of past climate change in the Mediterranean', Quaternary Science Reviews 136 (2016), 5-22. 
disposal, the easier and perhaps more severe this process of compression and conflation becomes. ${ }^{14}$

Yet, as soon as we compare processes of change closer to our own times and for which we have much better data, we can see the fallacy of this tendency. For example, in the course of the so-called Little Ice Age there occurred a number of periods of greater or lesser climatic instability, whether cooling or warming in trend. These had a range of often measurable impacts across the Old World and can be shown - combined with a range of other societal factors - to have affected the fabric and workings of the Ottoman empire as well as such events as the Dutch struggle for independence from Spain from the later sixteenth century onwards. Because we have precise data for some of these impacts, we can show how they led to qualitative shifts in the political as well as the societal evolution of the regions in question. We can trace how the power of both the Ottoman and Spanish empires was eroded, and how the international situation, the evolution of new technologies, the transformation of the global economy and the rise of new empires resulted, eventually, in the breakdown and fragmentation of these older empires. ${ }^{15}$ These processes lasted from two to three centuries. Yet we would not usually wish to describe any of these processes as 'collapse', in part because we have the evidence to reveal their relatively extended and multilayered character both spatially and chronologically; nor would we think of ascribing the 'collapse' of these imperial systems to the effects of the Little Ice Age alone. Yet, that is precisely what often occurs when the literature focuses on cases from prehistory or even the more recent ancient world.

To instead take a case less distant in time, for which the historical record is vastly more detailed, the fall of the Roman empire remains an enormously popular subject as an example of the 'collapse of civilizations' ${ }^{16}$ It can be made to appear as both a dramatic and a frightening example of the overwhelming of a culture by shifts in climate combined with pandemic disease and 'barbarian' invasion that resulted in an internal breakdown. But again, such depictions usually entailed the compression of generations of human experience into a few lines. We need to historicize those generations and put them back into the timescape of the culture they represent. Dramatic events there certainly were - the fall of Rome in C.E. 410, for example, was an event on which many contemporaries commented, often in texts that emphasize the

14 C. Caseldine, 'Conceptions of time in (paleo)climate science and some implications', WIREs Climate Change 3 (2012), 329-338.

15 See S. White, The climate of rebellion in the early modern Ottoman empire (New York 2011); G. Parker, Global crisis: war, climate change and catastrophe in the seventeenth century (New Haven 2013); D. Degroot, The frigid Golden Age. Climate change, the Little Ice Age, and the Dutch republic, 1560-1720 (Cambridge 2018).

16 E.g. R. Costanza, L. Graumlich and W. Steffen, eds., Sustainability or collapse? An integrated history and future of people on earth (Dahlem Workshop Reports. Berlin 2007), 3, where the Roman empire, the Maya and Easter island are lumped together as examples of collapse of the sort that threatens contemporary global civilisation. 
tragic character of the sack of the city and the doom-laden nature of the course of history. But these are, for the most part, literary works written by members of a relatively small social elite with particular aims in mind. This does not detract from the fact of the event, nor of what it signifies for the weakened structure and compromised resilience of the late Roman state in the west, but we should pay attention to the temporal, as well as the social, context of such utterances. There were barbarian attacks, cities were sacked, and the countryside was ravaged; there were occasional massacres and frequent violence against defenceless rural and urban populations. But such moments were neither generalized across a whole province nor did they affect more than a handful of population centres at any given time. Most people, and for much of the time, clearly carried on in the same old way, day in and day out, throughout most of the Roman world. Change was largely incremental, regionalized, and understood subjectively according to social status and cultural perception, punctuated by moments of actual harm and perceived crisis. We might wish to talk in terms of collapse or fall, but for most of the people who populated the late Roman world, the occasional (and for most, distant) calamity was neither unusual nor unexpected, whether this was a series of failed harvests or a barbarian incursion. And to repeat, we should not lose sight of the fact that our perception of what happened has been formed to a very large extent by the ideologically-loaded accounts of a tiny number of elite writers. This does not invalidate their testimony, but it does mean that they can hardly be representative of the vast mass of people in the Roman empire. By the time that the empire had actually faded away in the west, in the later fifth century, most people had never experienced the 'real' empire; rather, they had become acclimatized to the evolving moment - indeed they generally reinterpreted what they experienced in a way that let them perceive the old world continuing under new management. ${ }^{17}$ Such dramatic and fundamental transformations and sometimes violent changes can hardly be called a collapse (given the implication of rapidity and totality this usually imparts) without doing serious injustice to the actual course of events, the causal interrelationships, and the complexity of the societies and local cultures that comprised the Roman world.

\section{Human Agency}

If temporality is one crucial, yet largely neglected, element, then human agency is undoubtedly another. Yet, to take agency into account requires an engagement with beliefs and perceptions, at least as far as the available historical and material cultural evidence permits. How, and to what extent, did the people who were the vic-

17 See, e.g., T. Lewit, 'Pigs, presses and pastoralism. Farming in the fifth to sixth centuries A.D.', Early Medieval Europe 17 (2009), 77-91; C. Ando, 'Decline, fall and transformation', Journal of Late Antiquity 1 (2008), 31-60; K. Bowes and S. Loseby, 'Rethinking the later Roman landscape', Archaeology 18 (2005), 405-413. 
tims of any supposed 'collapse' themselves perceive events? The rhetoric of collapse tends inevitably to ignore or to minimize both the experiences and the responses of individuals and groups within the affected society. Human agency is obviously a key driver in all social systems. It is constrained by social-institutional boundaries, including the inherited culturally-determined rationalities of a society, kinship affiliations and identities, legal and bureaucratic structures and practices, the institutional arrangements of the dominant political organizations, the sets of socio-cultural relationships that define economic relations, and access to and consumption of resources. ${ }^{18}$ All these operate within the framework established by the interaction between environment and social action at multiple scales of analysis, and such interactions generate new or emergent practices or relationships. At the same time they alter the constitution or composition of the original elements. As has recently been noted, human agency has to be set within its ecological framework and be considered an element in the dynamics of change. ${ }^{19}$

Several studies have already emphasized the fact that human response to the climate is predicated on societal perception of the environment. ${ }^{20}$ Accordingly, a society's response to environmental stress depends upon how it recognizes and evaluates its own social and economic vulnerabilities in facing its environment. ${ }^{21}$ These responses, in turn, can - although they also may not - change the environment. In some cases, they can render certain environmental outcomes such as flooding

18 See, for example, the classic A. Schütz, Der sinnhafte Aufbau der sozialen Welt (Vienna 1960); also A. Callinicos, Making history. Agency, structure and change in social theory (Leiden and Boston 2004). 19 See the comments in P.B. de Menocal, 'Cultural responses to climate change during the late Holocene’, Science 292 (2001), 667-673; M.J. Hudson, M. Aoyama, K.C. Hoover and J. Uchiyama, 'Prospects and challenges for an archaeology of global climate change', WIREs Climate Change 3 (2012), 313-328. For a concrete case study, see, e.g. J.F. Haldon, The empire that would not die. The paradox of eastern Roman survival 640-740 (Cambridge, Mass. 2016), 12-21. See also C.J. Caseldine and C. Turney, 'The bigger picture: towards integrating palaeoclimate and environmental data with a history of societal change', Journal of Quaternary Science 25/ 1 (2010), 88-93.

20 P. Sheets and J. Cooper, 'Learning to live with the dangers of sudden environmental change', in J. Cooper and P. Sheets, eds., Surviving sudden environmental change (Boulder, Co. 2012), 1-18; R.J. McIntosh, J.A. Tainter and S.K. McIntosh, 'Climate, history, and human action', in R.J. McIntosh, J.A. Tainter and S.K. McIntosh, eds., The way the wind blows: climate, history and human action (New York 2000), 1-42; S.E. Van der Leeuw and C.L. Redman, 'Placing archaeology at the center of socio-natural studies', American Antiquity 67 (2002), 597-605; A.M. Rosen, Civilizing climate: social responses to climate change in the Ancient Near East (Lanham, MD 2007); V.D. Thompson, 'What I believe: reflections on historical and political ecology as research frameworks in Southeastern archaeology', Southeastern Archaeology 33 (2014), 246-254.

21 S.L. Dawdy, 'The taphonomy of disaster and the (re)formation of New Orleans', American Anthropologist 108 (2006), 719-730; M.C. Nelson, K. Kintigh, D.R. Abbott and J.M. Anderies 'The cross-scale interplay between social and biophysical context and the vulnerability of irrigation-dependent societies: archaeology's longterm perspective', Ecology and Society 15(3) (2010), no. 31; see also F.A. Hassan, 'Human agency, climate change and culture: an archaeological perspective', in S.A. Crate and M. Nuttall, eds., Anthropology and climate change: from encounters to actions (Walnut Creek Calif. 2009), 39-69. 
or crop failures more or less common. In others, being aware of the threat from an environmental challenge may still have no impact on how people responded to such events - as the examples of monument-building in the Moche Valley (Peru) during the later second millennium B.C.E discussed below illustrate.

Cultural and religious responses to premodern climate change and environmental stress are thus key elements to bear in mind in discussions of both longer-term as well as shorter-term or sudden, more dramatic, transformative moments in the experience of past societies. As we have just pointed out, human response to climate is predicated on societal perception of the environment. Vulnerabilities cannot be considered solely in the realm of subsistence and other elements of the economy. Ritual responses to climate stress and environmental disaster represent a relatively neglected topic of human interaction with the environment. Indeed many societies viewed (and in some cases continue to view) the environment in cosmological terms. ${ }^{22}$

Many agrarian communities understood drought, flooding, and torrential rain as supernatural phenomena that posed dangers to their agricultural systems and the populations that relied on them. Ritual served as an important aspect of human perception and response in the face of sudden changes, whether in environmental or other conditions. Rosen, for example, noted that increased temple-building coincided with a decrease in rainfall in the Levant during the Early Bronze Age (ca. 2200 B.C.E.). ${ }^{23}$ Continual temple building may have served as a means through which temple priests attempted to convince the population (and indeed themselves) of their control over rain deities. And although evidence is yet lacking, while such a response may possibly also have placed the society under greater pressure because of increased resource usage at a time of decreased rainfall, it might equally have relieved cultural/psychological pressure by offering potential explanations or solutions - as in the following example. ${ }^{24}$

In the very different case of medieval Gaelic Ireland, it may thus also be argued that religiously-informed perceptions of the environment governed responses to extreme weather in a way that may have helped in the shorter-term at the expense of the longer. Rituals and associated activities could help restore order during a crisis by mitigating certain adverse impacts, such as violence promoted by food scarcity, or triggered by the loss of credibility among ruling elites arising from (originally Pagan but soon Christianized) perceptions of sacral kingship that linked fitness to rule with

22 Rosen, Civilizing climate, 147.

23 An apparent upswing in the construction of religious settlements in early Christian Ireland has also been suggested to have occurred following the environmental dislocation of the famous C.E. 536 event; see P. McCafferty and M.G.L. Baillie, The Celtic gods: comets in Irish mythology (Stroud 2005).

24 A.M. Rosen, 'The social response to environmental change in Early Bronze Age Canaan', Journal of Anthropological Archaeology 14 (1995), 26-44; eadem, Civilizing climate, 147-148. 
the fertility of the land. ${ }^{25}$ But the energy expended on such mitigation activities, and indeed the persistent belief in their efficacy, may at the same time have lessened the impetus to develop agricultural adaptations to prevent food scarcity following adverse weather in the first place. Explicitly documented top-down societal mitigation responses to severe weather, related subsistence stress and societal disorder in Gaelic Ireland thus involved organized mass gatherings in which ecclesiastical and secular elites appealed to God for the return of clement weather and prescribed penance and other observances to be taken by the populace, as well as exhorting the populace to good behavior and enacting laws aimed at restoring order. ${ }^{26}$

These strategies were contingent upon the perception of extreme weather and its consequences as signs of divine displeasure or mechanisms for the delivery of divine punishment that must accordingly be addressed by clerical intercession on society's behalf and demonstrations of appropriate Christian 'kingly' behaviours. Whether the acceptance of such ritualized strategies also demotivated or supplanted more material climatic adaptations in Gaelic Irish agricultural practices remains an open question. It is notable, for example, that Gaelic Irish cattle-oriented agriculture suffered repeated heavy losses from extreme weather, ${ }^{27}$ yet there was little discernable effort to adopt remedial practices such as the storage of winter fodder, even though this was almost certainly known of by the Gaelic Irish, being practiced successfully in neighbouring and climatically similar Britain, and later even in the high medieval Anglo-Norman colony in Ireland itself. ${ }^{28}$

25 M. Fomin, 'The Early Medieval Irish and Indic polities and the concepts of righteous ruler', Cosmos 15 (1999), 163-197.

26 In a similar vein it has been suggested that the increased deposition of intact and broken swords at Flag Fen in England in the mid-to-late Bronze Age may be related to rising water levels and flooding of farmland, perhaps as a plea by locals to divine powers to halt or reverse it: see H. Chapman and B. Gearey, 'Iconoclasm in European prehistory? Breaking objects and landscapes', in S. Boldrick, L. Brubaker and R. Clay, eds., Striking images. Iconoclasms past and present (Abingdon 2013), 25-37. 27 F. Ludlow, A.R. Stine, P. Leahy, E. Murphy, P. Mayewski, D. Taylor, J. Killen, M. Baillie, M. Hennessy and G. Kiely, "Medieval Irish chronicles reveal persistent volcanic forcing of severe winter cold events, 431-1649 CE”, Environmental Research Letters 8:2 (2013), L024035.

28 For discussion of ecclesiastically mediated efforts to restore climatic and societal stability in medieval Gaelic Ireland, see F. Ludlow and C. Travis, 'STEAM approaches to climate change, extreme weather and social-political conflict', in A. de la Garza and T. Travis, eds., The STEAM Revolution: transdisciplinary approaches to science, technology, engineering, arts, humanities and mathematics (New York 2019), 33-65. See also L. Baker, S. Brock, L. Cortesi, A. Eren, C. Hebdon, F. Ludlow, J. Stoike and M. Dove, 'Mainstreaming morality: an examination of moral ecologies as a form of resistance', Journal for the Study of Religion, Nature, and Culture, 11/1 (2017), 23-55. For further discussion of Gaelic Irish agricultural vulnerability to extreme weather and the 'failure' to store winter fodder, including remarks by medieval British visitors to Ireland reflecting upon the apparent oddity of this choice, see A. Keleman, S. Brock, L. Cortesi, C. Hebdon, A. Johnson, F. Ludlow and M.R. Dove, 'Indigenous agriculture and the politics of knowledge', in P. Sillitoe, ed., Indigenous knowledge: enhancing its contribution to natural resources management (Cambridge and Wallingford 2017), 203217. These authors explore the likelihood that this choice was based upon an implicit cost-benefit analysis in which Gaelic Irish society played (but periodically failed) on the odds of characteristically 
Many further cases exist in other cultures and parts of the world. For example, an investigation of second millennium B.C.E. monuments on the coast of Peru, normally an arid region, documented that they were subjected to the El Niño phenomenon in which heavy rainfall, flooding and debris flows damaged ancient agricultural fields and settlement. ${ }^{29}$ Excavation of Huaca Cortada, a large monument in the Moche Valley, revealed the direct association of laminated flood deposits, which were formed during periods of heavy rain, and cycles of monument rebuilding during the period between ca. 1600 and 1000 B.C.E. ${ }^{30}$ Like Rosen, Nesbitt argued that the renewal of temple architecture was part of an effort by religious leaders to demonstrate control over natural forces by maintaining an important symbol of community ties to a dynamic landscape. Ritual responses appear in other types of contexts and scales. For example, a recent study documented how ritual practice in caves changed during periods of climate stress in the Maya region. Among the ancient Maya caves were associated with gods that controlled ecological forces, such as water and agricultural fertility. During a period of prolonged drought during the Late to Terminal Classic Period (ca. C.E. 680 -950) certain Maya populations intensified cave rituals as a means to placate rain deities and mitigate against climate stress. ${ }^{31}$ In other parts of the world, similar kinds of ritual were invoked in the face of drought. ${ }^{32}$ The point here is not to belabour the obvious, but rather to insist that such responses reflect perceptions and ways of understanding the world that directly impacted social action and that need to be taken into account in our analyses of both systemic fragmentation as well as social resilience and vulnerability.

mild Irish winters outnumbering cold winters harmful to their pastoral agriculture. This would have helped preclude the need for the adoption of British agricultural practices that were also potentially less culturally suitable to Ireland, given the endemic practice of cattle raiding that lent advantage to constant mobility of cattle. If correct, this may itself have motivated Gaelic Irish society to gravitate to short-term ecclesiastical mitigation mechanisms, rather than the other way around (as suggested in the main text), or indeed created a positive feedback that further encouraged the observed forms of mitigation versus longer-term adaptation.

29 T. Dillehay and A. Kolata, 'Long-term human response to uncertain environmental conditions in the Andes', Proceedings of the National Academy of Science 101/12 (2004), 4325-4330; D.H. Sandweiss, K.A. Maasch, R.L. Burger, J.B. Richardson III, H.B. Rollins and A. Clement, 'Variation in Holocene El Niño frequencies: climate records and cultural consequence in ancient Peru', Geology 29 (2001), 603-606; M. van Buren, 'The archaeology of El Niño and other "natural" disasters', Journal of Archaeological Method and Theory 8 (2001), 129-149.

30 J. Nesbitt, B. Gutiérrez and S. Vásquez, 'Excavaciones en Huaca Cortada, Complejo Caballo Muerto: un informe preliminar', Boletín de Arqueología PUCP 12 (2008), 261-286; J. Nesbitt, 'El Niño and second- millennium BC monument building at Huaca Cortada (Moche Valley, Peru)', Antiquity 90/351 (2016), 638-653.

31 H. Moyes, J.J. Awe, G.A. Brock and J.W. Webster, 'The ancient Maya drought cult: Late Classic cave use in Belize', Latin American Antiquity 20 (2009), 175-206.

32 T.N. Huffman, 'A cultural proxy for drought: ritual burning in the Iron Age of southern Africa', Journal of Archaeological Science 36 (2009), 991-1005. 
All historically-known polities have been legitimated through political/theological systems. These have reinforced the world-view of the state and its elites through ritualized expressions of faith and the redistribution of considerable amounts of surplus wealth to religious foundations of various types or through a range of ideologically legitimating ritual actions. Such systems penetrated throughout society, inflecting daily life in myriad ways. The institutionalisation of Hinduism, Islam, or Christianity (along with many other religious systems) in many societies and the 'ritual penetration' of the latter through observance and a particular moral universe directly impacted people's perceptions and understanding of their world and, consequently, the actions they took to address the problems they perceived within it, as the examples from the Maya area and early Byzantium, discussed below, will further demonstrate. ${ }^{33}$

Considerations of this sort remind us that we need to bear in mind the nature of human experience - when we speak of 'collapse', even where we can show that the processes of change and transformation took place over a relatively short period, hence adhering more closely to the most widespread conception of collapse, we should be aware that those who experienced the historical events in question may not have been aware (and indeed might not agree) that anything was collapsing at all, even if they did perceive rapid change. ${ }^{34}$ Collapse is our definition of the events that we can detect with historical and archaeological data. How clear was what we call a collapse in the minds of those who lived through it? And should it be labelled collapse if the processes we discern were, in fact, enacted at least partly by deliberate intent in response to environmental and other changes perceived by contemporaries to these events? ${ }^{35}$ Given the ongoing discussion about 'managed retreat' in the face of present and projected environmental pressures (e.g., deliberately relocating from or repurposing of areas in the face of sea level rise), ${ }^{36}$ it is plausible to hypothesize that

33 J.F. Haldon and J. Goldstone, 'Introduction: ancient states, empires and exploitation: problems and perspectives', in I. Morris and W. Scheidel, eds., The dynamics of ancient empires: state power from Assyria to Byzantium (Oxford 2009), 3-29, see 10 -15. For a good example, see P. Brown, The rise of western Christendom (Oxford 2003), 25-34. For Mesoamerican examples, see A.F. Chase, D.Z. Chase and M.E. Smith, 'States and empires in Mesoamerica', Ancient Mesoamerica 20 (2009), $175-182$.

34 See P. Ricoeur, Time and narrative, trans. K. McLaughlin and D. Pellauer (Chicago 1988).

35 This would certainly seem to be what various American Southwest tribes would feel - in their oral histories, they do indeed tell of moving on periodically and 'abandoning' quite extensive settlement complexes - seen as 'moving' when the time became appropriate for various reasons, including environmental change. See M.C. Nelson, M. Hegmon, S. Kulow and K.G. Schollmeyer, 'Archaeological and ecological perspectives on reorganization: a case study from the Mimbres region of the U.S. Southwest', American Antiquity 71(3) (2006), 403-432; M.C. Nelson, K. Kintigh, D.R. Abbott and J.M. Anderies, 'The cross-scale interplay between social and biophysical context and the vulnerability of irrigation-dependent societies: archaeology's longterm perspective', Ecology and Society 15(3) (2010), no. 31.

36 For literature on this topic, see M. Hino, C.B. Field and K.J. Mach, 'Managed retreat as a response to natural hazard risk', Nature Climate Change 7 (2017), 364-370. 
members of past societies adopted similar responses in the face of various pressures (as opposed to disorganized mass flight, mass mortality or societal breakdown leading to a lesser state of socioeconomic complexity without any conscious agency). ${ }^{37}$ As we have intimated already, 'collapse' is something that tells us more about what (and who) we - the observers/researchers - deem important, and hence discussions of collapse are, as often as not, more about our use of the past to talk about ourselves. ${ }^{38}$

\section{Reframing the concept of collapse}

It seems sensible, therefore, to define more closely what we want 'collapse' to mean. Our basic premise is that it should be used in keeping with its primary (and generally accepted) meaning of something that takes place relatively rapidly, involves a substantial change of state, and systemic failure. ${ }^{39}$ It is clear that many supposed 'collapses' in fact extended over centuries, which renders use of the word collapse somewhat problematic. Notions of 'slow collapse' have been introduced in part to explain or account for this. ${ }^{40}$ We would suggest that such a term does not really address the key problem, which remains one of perception - and continued use of the word collapse really negates the value of any such inflection.

Cumming and Peterson have argued for clear criteria through which collapse can be described and through which it can be recognized, using quantitative thresholds to identify collapse and suggesting that theories of collapse must connect structure and process. ${ }^{41}$ System structure is a crucial influence on the types of collapse (i.e. whether or not a system collapses from the base up or top down, or incrementally) that may occur, so the notion of 'system identity' offers a good starting point, since it helps define those key structural elements that must be maintained across time and space for any system to have maintained coherence. Defining such systemic properties is achieved by determining the thresholds beyond which they can be said to have

37 This seems, in fact, to share some features with Weiss and Bradley's elaboration on the concept of collapse as being itself an adaptation to environmental and other pressures: see H. Weiss and R. S. Bradley, 'What drives societal collapse?', Science 291 (2001), 609-610, although leaving the definition of 'collapse' unresolved.

38 An issue also taken up from a methodological perspective with respect to research design in V.P.J. Arponen, W. Dörfler, I. Feeser, S. Grimm, D. Groß, M. Hinz, D. Knitter, N. Müller-Scheese, K. Ott and A. Ribeiro, 'Environmental determinism and archaeology. Understanding and evaluating determinism in research design', Archaeological Dialogues (2019), 1-11.

39 E.g. definitions in the New Shorter Oxford English Dictionary, s.v. 'collapse'.

40 R. Storey and G.R. Storey, Rome and the Classic Maya: comparing the slow collapse of civilizations (New York 2017).

41 G.S. Cumming and G.D. Peterson, 'Unifying research on social-ecological resilience and collapse', Trends in Ecology and Evolution 32(9) (2017), 695-713, cited and deployed also by Strunz et al. 'Leaving the "sustainability or collapse" narrative behind'. 
become qualitatively something else. ${ }^{42}$ In resilience theory parlance, this should equate to when a former stable state 'flips' into a new one, the resilience of the first system being insufficient to cope with whatever challenges it is facing. Thus for 'collapse' to have taken place, four conditions should apply: (1) the systemic identity of the system must be lost (key system components and relationships such as social groups, institutional arrangements, economic relationships, etc. must disappear); (2) these changes should happen rapidly (within years and decades rather than centuries); (3) the immediate consequences of the shifts defined as collapse must last longer than the characteristic dynamics of the system (simply put, the way things formerly worked), and they should be irreversible; and finally, (4) there must be a substantial loss of system capital, ${ }^{43}$ that is to say that key thresholds in respect of the form and/or operation of a range of socio-cultural assets - such as demography, commercial and market exchange circuits, elite composition, cultural production and knowledge, system of governance and the transmission of political power, and so forth - must be breached. A rapid transition beyond such identifiable tipping-points of all four instances means that the system as a whole has collapsed. A much slower, more differentiated process of change, whereby the chronologies or rate of change of these four key stages neither coincide nor happen at the same pace, may be more usefully described as a transformation. ${ }^{44}$

Ecologists and other natural scientists and mathematicians were among the first to think about what constitutes a collapse and how to deconstruct the processes it would embody. ${ }^{45}$ Ecosystems are complex adaptive systems - heterogeneous collections of individual units or agents that interact locally and evolve as a consequence of the outcomes of those interactions - and it is clear that social systems can be understood in a similar way. ${ }^{46}$ 'Collapse' has been recognized as always a multi-aspect

42 While the approach is derived from ecological science it is not difficult to transfer it to a socialscience, including a historical, context: G.S. Cumming and J. Collier, 'Change and identity in complex systems', Ecology and Society 10(1) (2005), no. 29; D. Stauffer, Introduction to percolation theory (London 1985).

43 N. Abel, D.H.M. Cumming and J.M. Anderies, 'Collapse and reorganization in social-ecological systems: questions, some ideas, and policy implications', Ecology and Society 11(1) (2006), no. 17. 44 Cumming and Peterson, 'Unifying research on social-ecological resilience and collapse', box 1. 45 R.H. May, 'Thresholds and break points in ecosystems with a multiplicity of stable states', Nature 269 (1977), 471-472; J.H. Steele, 'Regime shifts in marine ecosystems', Ecological Applications 8/1 (1981), S33-S36.

46 The adaptive capacity of a socio-economic and cultural system takes account of key systemic elements: natural capital (landscape resources and potentials); physical capital (labour resources and infrastructure); human capital (skills, competences, technological know-how); systemic redundancy (diversity of functionally similar elements that can replace one another); and institutional structures and differential access to resources. See S.A. Levin et al., 'Social-economic systems as complex adaptive systems: modelling and policy implications', Environment and Development Economics 18/2 (2013), 111-132; M. Scheffer, Critical transitions in nature and society (Princeton 2009). See also L.H. Gunderson and C.S. Holling, eds., Panarchy: understanding transformations in human and natural systems (Washington DC 2002); R.L. Flood, 'Liberating systems theory: toward critical systems 
or multi-level phenomenon (not everything necessarily collapses at the same time and at the same rate) and is, thus, most readily understood through thinking in terms of systems. ${ }^{47}$ If we look at collapse as a set of systemically related or interconnected developments, we must be careful at the same time not to assume that 'the system' is so all-encompassing that everything is dependent upon its cohesion, ${ }^{48} \mathrm{a}$ tendency that can be avoided if we consider cultural as well as socio-economic systems as networks of agents or actors with a range of different organizational levels and potentials.

From this perspective, collapse can best be understood as a rapid reduction or loss of levels of organization and/or reduction in spatial, as well as socio-economic, complexity; ${ }^{49}$ but it needs also to be framed in terms of the actors or agents who experienced it - subjectively, collapse should, because of its rapidity and extent, be perceptible in some or all of its effects by the members of the affected socio-cultural system. Different levels of social structure or systems may be affected in different degrees and at different paces, indeed a 'collapse' at one level may not necessarily impact other levels in any dramatic or fundamental way. In a broader perspective, understanding collapse involves framing our questions within a complex adaptive systems approach, which facilitates an appreciation both of how societal arrangements developed in the way they did - how the different sets of competitive and emergent social practices evolved - and how they generated the specific outcomes we observe in our data. ${ }^{50}$

thinking', Human Relations 43/1 (1990), 49-75; P. Graham, ‘Critical systems theory', Communication Research 26/4 (1999), 482-507; A. Fischer-Lescano, 'Critical systems theory', Philosophy and Social Criticism 38/1 (2012), 3-23.

47 K.W. Butzer, 'Collapse, environment, and society', Proceedings of the National Academy of Sciences 109(10) (2012), 3632-3639; C.S. Holling, 'Understanding the complexity of economic, ecological, and social systems', Ecosystems 4/5 (2001), 390-405.

48 See, e.g. Latour's actor-network theoretical approach and his critique of the potential 'totalitarianism' of systems-based thinking: B. Latour, Reassembling the Social: an Introduction to Actor-Network-Theory (Oxford 2005).

49 As does J.A. Tainter, The collapse of complex societies (Cambridge 1988); idem, 'Problem solving: complexity, history and sustainability', Population and Environment: a journal of Interdisciplinary Studies 22 (2000), 3-41: collapse is related to the degree of complexity of the society in question, linked in turn to diminishing marginal returns on investment in infrastructure and other societal goods. Collapse occurs when a society rapidly loses an established level of sociopolitical complexity, where 'established' refers to a period of more than a couple of generations, and where 'complexity' refers to size, role specialisation, institutional, socio-economic and cultural differentiation and hierarchisation, differential access to resources and power, and multi-level functional organization in respect of political, economic and cultural life. Collapse is the result of a loss of sociopolitical coherence and identity.

50 See S. Lansing, 'Complex adaptive systems', Annual Review of Anthropology 32/1 (2003), 183-204 and J.H. Miller and S.E. Page, Complex Adaptive Systems. An introduction to computational models of social life (Princeton 2007), 3-31. 


\section{Collapse and Palaeoclimate}

As we have stressed, the conflation of events and cultural experience, the flatteningout of inter-regional and micro-regional differences, the ignoring of temporal as well as spatial scale, all contribute to interpreting major historical transformations under the rubric of 'collapse', in which the dramatic and catastrophic are foregrounded at the expense of complexity and variation. As an illustration we can take the so-called 4.2 and 3.2 kya ('thousand years ago') events, where extended drought (demonstrated in the palaeoclimatic and environmental record, although also clearly varying in impact and potential outcomes from region to region) ${ }^{51}$ in the eastern Mediterranean and Levant is supposed to have led to simultaneous widespread collapse among several neighboring cultural systems..$^{52}$ No-one challenges the fact of significant cultural change, accompanied by or promoting significant political and infrastructural transformations - the archaeology and the sparse but indicative historical documentation makes the nature of such changes clear enough. Yet as soon as we examine them in detail it becomes apparent that the processes of change varied by region and varied in pace; that they did not necessarily bring with them a breakdown in all levels of social, economic or cultural life; that they did not in all cases entail the disintegration of state systems, and that where they did, there was a whole range of socio-political and cultural factors at play, so that change was not always either simultaneous or to be ascribed to climate events alone..$^{53}$

51 E.g. M. Bini, G. Zanchetta, A. Persoiu, R. Cartier, A. Català, I. Cacho, J.R. Dean, F. Di Rita, R.N. Drysdale, M. Finnè, I. Isola, B. Jalali, F. Lirer, D. Magri, A. Masi, L. Marks, A.M. Mercuri, O. Peyron, L. Sadori, M.-A. Sicre, F. Welc, C. Zielhofer and E. Brisset, 'The 4.2ka BP Event in the Mediterranean Region: an overview', Climate of the Past 15 (2019), 555-577.

52 For example, and from a very large number of studies: H.N. Dalfes, G. Kukla and H. Weiss, eds, Third millennium BC climate change and Old World collapse (Berlin 1997); H. Weiss, ed., Megadrought and collapse: from early agriculture to Angkor (Oxford 2017); D. Kaniewski, N. Marrine, J. Bretschneider, G. Jans, C. Morhange, R. Cheddadi, T. Otto, F. Luce, E. Van Campo, '2300-year drought frames Late Bronze Age to Early Iron Age transition in the Near East: new palaeoecological data from Cyprus and Syria', Regional Environmental Change 19 (2019), 2287-2297 (noting the need for higher-resolution archaeologically-based palaeoenvironmental studies in order to generate plausible causal relationships); D. Kaniewski, E. Paulissen, E. Van Campo, H. Weiss, T. Otto, J. Bretschneider and K. Van Lerberghe, 'Late second-early first millennium BC abrupt climate changes in coastal Syria and their possible significance for the history of the Eastern Mediterranean', Quaternary Research 74 (2010), 207-215; and with a more nuanced approach M.H. Wiener, 'The interaction of climate change and agency in the collapse of civilizations ca. 2300-2000 BC', Radiocarbon 56/4 (2014), S1-S16 (also: Tree-Ring Research 70/ 3 (2014), S1-S16).

53 A recent balanced assessment: A.B. Knapp and S.W. Manning, 'Crisis in context: the end of the Late Bronze Age in the eastern Mediterranean', American Journal of Archaeology 120 (2016), 99149; see also Caseldine and Turney, 'The bigger picture' (n. 19 above); and S. Kerner, R.J. Dann and P. Bangsgaard, eds., Climate and Ancient Societies (Copenhagen 2015). For some methodological and practical considerations in approaching archaeological interpretation in environmental-historical contexts, see the contributions to P. Leaveau, F. Trément, K. Walsh and G. Barker, eds., Environ- 
Recent and ongoing work in eastern and central Anatolia reinforces this general picture. The Bronze Age site of Kültepe (Assyrian Kanesh, Hittite Nesha), some 20 km to the northeast of the modern city of Kayseri, was the main settlement of the ancient Kingdom of Kanesh. It was also the focus of a complex network of Assyrian trade colonies. Founded ca. 3550 B.C.E. during the Late Chalcolithic (during relatively favourable climatic conditions), the settlement reached its apogee ca. 2500 B.C.E. during the early-to-middle Bronze Age. Stable isotope and other environmental proxy data from Engir Gölü and the slightly more distant Lake Nar indicate the swing to arid conditions occurred at 2200 B.C.E (corresponding to the 4.2 ka BP 'Meghalayan' aridity event), which persisted for some time. The archaeological evidence, however, clearly shows that ca. 2100 B.C.E., while Kültepe was less wealthy, there was settlement continuity, with the first indications of a settlement reduction ca. 1970 B.C.E and a revival after a major conflagration ca. 1835 B.C.E. ${ }^{54}$ At Kültepe, therefore, although there is very good evidence of climate change and aridity in Cappadocia via the stable isotope data, and while this 'global' aridity event may have had some impact on the region's socio-economic viability, Kültepe did not collapse in any meaningful sense of the term at this point. Indeed final abandonment occurred only in ca. 1700 B.C.E., fully 550 years after the shift to greater aridity. Far from being an example of collapse, therefore, we have good evidence here for what is most probably a good case of adaptation. ${ }^{55}$

mental reconstruction in Mediterranean landscape archaeology (Oxford 2016); and the useful short critical note by Y. Jaffea, G. Bar-Oza and R. Ellenblum, 'Improving integration in societal consequences to climate change', Proc. National Acad. of Sciences of the USA 116/11 (2019), 4755-4756.

54 See L. Atici, F. Kulakoğlu, G. Barjamovic and A. Fairbairn, eds., Current research at Kültepe-Kanesh: an interdisciplinary and integrative approach to trade networks, internationalism, and identity (Bristol, Ct. 2014) with further literature; also A. Fairbairn, F. Kulakoğlu and L. Atici, 'Archaeobotanical evidence for trade in hazelnut (Corylus sp.) at Middle Bronze Age Kültepe (c. 1950-1830. B.C.), Kayseri province, Turkey', Vegetation History and Archaeobotany 23/2 (2014), 167-174; K.A. Yener et al., 'New tin mines and production sites near Kültepe in Turkey: a third-millennium BC highland production model', Antiquity 89345 (2015), 596-612.

55 There are other illustrations of this point from other periods. To take one example: it has generally been assumed that the Negev region was in Roman times a 'green desert', and that the eastern empire withdrew from the region in the sixth century C.E. due to a dramatic climatic downturn. Analysis of stable isotope data - among other datasets - has recently shown first that the Negev Desert was no greener in the Roman and early medieval period than it is today, and that livestock dietary and grazing patterns remained unchanged from Roman into early Islamic times. The abandonment of the Byzantine settlements in the Negev was far more probably motivated by changing strategic territorial concerns: P. Vaiglova, G. Hartman, N. Marom, A. Ayalon, M. Bar-Matthews, T. Zilberman, G. Yasur, M. Buckley, R. Bernstein, Y. Tepper, L. Weissbrod, T. Erickson-Gini and G. Bar-Oz, 'Climate stability and societal decline on the margins of the Byzantine empire in the Negev Desert', Scientific Report/Nature Research 10 (2020), 1512. https://doi.org/10.1038/s41598-020-58360-5. 
The combination of 'megadrought' and ancient collapse remains a potent discourse in collapse studies in archaeology and more widely. ${ }^{56}$ Illustrative of this is the recent (2018) declaration from the International Commission on Stratigraphy of a new geological unit within the Holocene - the Meghalayan, which, according to their announcement, began with the widespread and causally interlinked collapse of numerous civilizations in Egypt, Greece, Syria, Palestine, Mesopotamia, the Indus Valley, and the Yangtze River Valley. ${ }^{57}$ Of course, the claim for widespread drought-induced famines and collapse is not new, ${ }^{58}$ but even where the data for the general situation is persuasive, sub-regional and local variation and regional heterogeneity needs to be considered more carefully than has often been the case. ${ }^{59}$ But the particular problem here is that whatever the climatological evidence for the period $2200-2000 / 1900$ B.C.E., the characterization of the period as one of global collapse is highly problematic. Firstly, because it does scant justice to the variety and multi-faceted character of change in the various regions concerned, and secondly because it offers an entirely negative characterization of change as a human catastrophe - an apocalyptic view that represents humans as passive victims of natural disaster, rather than as active agents of change within their own communities and beyond. ${ }^{60}$ Is the collapse of the Akkadian Empire comparable with the material changes in very small-scale societies in Greece? Are either of these comparable to the de-urbanisation in the Levant or the Indus Valley, or the devolution and fragmentation of power in Egypt from a centralized to a local, but still complex level? In none of these cases is there any real evidence of mass mortality, for example; indeed, clear continuities of population and material culture (even when different in kind) show that the opposite is the case - if there was a two- or three-century megadrought, people clearly weathered it; while in the Andes, to mention but one example, this is a period of cultural efflorescence, with the first Late Preceramic monuments (2500 1700 B.C.E.). Any megadrought may provide only a background context in such cases rather than the prime driver of change.

The archaeological and textual evidence clearly demonstrates that neither Mesopotamian nor Egyptian society disappeared, even though both became decentral-

56 For example, H. Weiss, ed., Megadrought and collapse; M. Le Page, 'Did ancient Mayan civilisation collapse because of a sudden drought?' (2018): https://www.newscientist.com/article/2175823-didancient-mayan-civilisation-collapse-because-of-a-sudden-drought/

57 The International Commission on Stratigraphy, 'Collapse of civilizations worldwide defines youngest unit of the Geologic Time Scale’ (2018) http://www.stratigraphy.org/index.php/ics-newsand-meetings/119-collapse-of-civilizations-worldwide-defines-youngest-unit-of-the-geologic-timescale

58 E.g. H. Weiss, '4.2 Ka BP megadrought and the Akkadian collapse', in Weiss, ed., Megadrought and collapse, 93-159.

59 See, for example, the cautious conclusions of M. Bini et al., 'The 4.2ka BP Event in the Mediterranean region: an overview', Climate of the Past 15 (2019), 555-577.

60 Although again, we might note the more nuanced approach of 'collapse as adaptation': H. Weiss and R. S. Bradley, ‘What drives societal collapse?’, Science 291 (2001), 609-610. 
ized, which in Mesopotamia, a land of usually autonomous 'city-states', was the norm in any case. After a short time, Mesopotamia, which continued to be the home of complex societies, was reunified by the Ur III dynasty - during the period of the supposed megadrought - though this empire too broke down after around a century, probably for similar reasons to the fragmentation of the Egyptian Old Kingdom. ${ }^{61}$ But the decentralization of power in Egypt was in no way disastrous, except for those with a vested interest in the operation of pharaonic control and ideology, as is apparent from Middle Kingdom literature such as the Dialogue of Ipuwer that offered critical comment on the period. ${ }^{62}$ The First Intermediate Period was a culturally dynamic time in which there were still sufficient resources for local potentates to feed their armies. ${ }^{63}$ In China, while some polities disappeared, the formation of the Erlitou state was taking place, ${ }^{64}$ again challenging the view that a megadrought was uniformly a global disaster; while in Greece, it is difficult to see how the visible change in culture is indicative of megadrought rather than population continuity.

The universal nature of collapse, and by extension the effects of any $4.2 \mathrm{kya}$ megadrought, for example, is thus overplayed. In China, developmental trajectories were varied and in the Levant and in the Harappan culture of the Indus Valley patterns of de-urbanisation and settlement distribution differed by region. In Greece change in the Early Bronze Age is not marked by a sudden or complete break, indeed the 'new' culture of the late Early Helladic III rather overlapped in time with the culture it eventually replaced, strongly suggesting internal changes in social and political values rather than mass famine or invasion. ${ }^{65}$ Egyptian fragmentation was most likely the result of administrative changes made much earlier, the consequences of which were not sufficiently dealt with by the central administration. ${ }^{66}$

The idea of sudden, rapid, and synchronous change at this period must, on the basis of recent archaeological work, also be abandoned. The visible changes in Early Bronze Age Greece, architectural and material, were gradual, not sudden as once

61 K.W. Butzer, 'Collapse, environment, and society', Proceedings of the National Academy of Science of the USA 109/10 (2012), 3632-3639; D.B. Redford, Egypt, Canaan and Israel in ancient times (Princeton 1992), 61-62.

62 J.C. Moreno Garcia, 'Climatic change or sociopolitical transformation? Reassessing late 3rd millennium BC in Egypt', in H. Meller, H.W. Arz, R. Jung and R. Risch, eds., 2200 BC - a climatic breakdown as a cause for the collapse of the Old World? (Halle 2015), 3-16.

63 E. Morris, “Lo, nobles lament, the poor rejoice': state formation in the wake of social flux', in Schwartz and Nichols, eds., After collapse: the regeneration of complex societies, 58-71; S. Seidlmayer, 'The First Intermediate Period (c. 2160 - 2055 BC)', in I. Shaw, ed., The Oxford History of Ancient Egypt (Oxford 2000), 108-136.

64 F. Liu and Z. Feng, 'A dramatic climatic transition at 4000 cal. yr BP and its cultural responses in Chinese cultural domains', The Holocene 22 (2012), 1181-1197.

65 J. Forsén, 'Mainland Greece', in E. Cline, ed., The Oxford Handbook of the Aegean Bronze Age (Oxford, 2010), 53-65; E. Weiberg and M. Lindblom, 'The Early Helladic II-III transition at Lerna and Tiryns revisited: Chronological difference or synchronous variability', Hesperia 83(3) (2014), 383407, at 399.

66 T. Wilkinson, The rise and fall of ancient Egypt (London 2010), 116-112. 
thought; ${ }^{67}$ the end of the Akkadian Empire has a range of dates, only some of which place its rise in the period of megadrought; ${ }^{68}$ the Levantine de-urbanisation took place over centuries, before the start of the Egyptian Old Kingdom; ${ }^{69}$ the de-urbanisation and eastward shift in settlement in the Harappan culture was also a long process, and one with more cultural continuity than often suggested. ${ }^{70}$ In China too, there is uncertainty about precise dates, which is admitted even by those who support a drought-induced change. ${ }^{71}$

Similar considerations apply for different periods to many of the civilizational systems that apparently or supposedly suffered 'collapse'. The fate of the Khmer empire in the fifteenth century C.E., for example, once supposed to have suffered a dramatic collapse, has now been shown, as the result of more carefully-delineated analyses of the data and the development of a more refined chronology, to have entailed both longer-term social-political changes involving elite migration away from Angkor, on the one hand, as well as the continued existence of the empire but with a different geographical focus - so, in a word, no actual 'collapse' but merely a significant transformation in political and socio-economic organization. ${ }^{72}$ And as we shall see below, the transformation and ultimate extinction of the Classic Maya is far more complex, nuanced and temporally differentiated than the term 'collapse' permits. The list could be extended. The point here is not to suggest that no major societal and structural shifts took place, but rather that in most cases change took place over many decades if not centuries, was regionally varied in intensity and pace, and occurred at different levels of social-economic life with varying impacts. A focus on 'collapse' as the central explanatory framework thus serves in most cases to undermine the recognition and understanding of this more complex reality.

67 Forsén, 'Mainland Greece'.

68 Butzer, 'Collapse, environment, and society'; idem, 'Supporting information', at https://www. pnas.org/content/109/10/3632; R.L. Zettler, 'Reconstructing the world of ancient Mesopotamia: Divided beginnings and holistic history', Journal of the Economic and Social History of the Orient 46 (2003), $3-45$.

$69 \mathrm{H}$. Genz, 'Beware of environmental determinism: The transition from the Early to the Middle Bronze Age on the Lebanese coast and the 4.2 ka BP event', in Meller et al., eds., 2200 BC - A climatic breakdown, 97-111; F. Hoflmayer, 'The southern Levant, Egypt, and the 4.2 ka BP event', ibid., 113130.

70 J. Kenoyer, 'The archaeological heritage of Pakistan: From the Palaeolithic to the Indus Civilization', in R. Long, ed., History of Pakistan (Oxford, 2015), 1-90.

71 Liu and Feng, 'A dramatic climatic transition at 4000 cal. yr BP'.

72 See R. Fletcher, B.M. Buckley, C. Pottier and S.-Y. S. Wang, 'The Case of Angkor and monsoon extremes in mainland Southeast Asia', in Weiss, ed., Megadrought, 276-307; B.M. Buckley, K.J. Anchukaitis, D. Penny, R. Fletcher, E.R. Cook, M. Sano, Le Canh Nam, A. Wichienkeeo, Ton That Minh and Truong Mai Hong, 'Climate as a contributing factor in the demise of Angkor, Cambodia', Proceedings of the National Academy of Sciences, 107(15), 6748-6752. 


\section{Challenging collapse: belief, environment, response}

Rather than presenting major transformative periods in terms of collapse, therefore, it would be far more profitable and heuristically enlightening to try to establish why some systems proved more resilient or sustainable than others, and what were the qualities and conditions that made them so. To approach such issues we should focus on the details of specific cases to analyze local impacts and responses, while at the same time keeping in mind the broader spatial and temporal contexts of those cases. Such an approach facilitates the detailed analysis of specific historical-environmental conjunctures by focusing research on case-studies for micro-regions or groups of micro-regions for which the various types of data - written, archaeological and palaeoenvironmental - are available in sufficient quantity to permit us to correlate and cross-check across disciplines and data-types. A common starting point is to home in on regions that represent important zones of civilizational development, where climate and social scientists have demonstrated at the very least an apparent correlation between major societal shifts and potential environmental factors such as climate change or major disasters. This minimizes the range of interpretive options open to us in trying to understand both the mechanics of societal responses to environmental and climatic change, on the one hand, as well as, on the other, the nature of the dialectic between 'anthropogenic' and 'natural' complex systems. Analyzing case studies according to these criteria disentangles the exact form of the causal association between society and environment. ${ }^{73}$

We now present summaries of two case studies in which a fuller range of societal activity, as derived from historical and archaeological sources, has been taken into account and tied in with the proxy data for a range of environmental phenomena. Our examples are illustrative of historical developments that have been described under the rubric of collapse, but where, upon closer examination, it seems that this may not be an appropriate description, indeed it may be positively misleading and encourage a misidentification of causes and effects - which in turn leads to a more generalized misunderstanding of both the periods and cultures in question, on the one hand, and a more general misapprehension of the causal relationships that pertained, on the other. The types of evidence available in each case are different, but the results illustrate both the complex interrelationship of environment and society, and the importance of building social agency and belief into interpretations of historical change, as well as rethinking exactly what we want the term 'collapse' to mean. Our second case study also provides an object lesson in the need to examine very carefully the complexity of the relationship between social/cultural/economic

73 J.F. Haldon, N. Roberts, A. Izdebski, D. Fleitmann, M. McCormick, M. Cassis, O. Doonan, W.J. Eastwood, H. Elton, S. Ladstätter, S. Manning, J. Newhard, K. Nichol, I. Telelis and E. Xoplaki, 'The climate and environment of Byzantine Anatolia: integrating science, history and archaeology', Journal of Interdisciplinary History 45 (2014), 113-161. 
structures, environment, and conjuncture and to take each case on its own specific merits. For in the case of the Maya we can see, in the contrast between radically different outcomes, but from comparable developments within the same cultural system many centuries apart, examples of both resilience and what with current evidence appears to be genuine collapse.

\section{Byzantium - the collapse that never happened}

One of the puzzles for historians of the early medieval western Eurasian world has been how the eastern part of the Roman empire - generally referred to as the Byzantine empire from the sixth century onwards - survived the onslaught of the Islamic invasions which deprived it of maybe two-thirds of its territory and up to three-quarters of its revenue within a short period of less than ten years (C.E. 633-641). ${ }^{74}$ Indeed it was hit by two separate sets of invasions, since at the same time it also lost control over most of its Balkan territories and what was left of the North African provinces. The powerful Islamic caliphate now faced it in the east, launching a series of annual raids punctuated by major attacks against the capital, Constantinople (in the C.E. 650s, 668-9 and 717-8) (see Fig. 1a and b). ${ }^{75}$

One might ask how any complex state formation could survive such enormous losses in terms of fiscal resource, territory and demographics, yet survive it did. And while the history of the eastern Roman state after the later sixth century is frequently described in terms of collapse, upon closer examination it is clear that things are far less straightforward, and that once again the vocabulary of collapse misleads rather than informs. Indeed, not only did it survive, but it recovered and became a major international power dominating the eastern Mediterranean basin by the tenth century. The sixth-century East Roman state was a complex system with regard to: (1) size (spatially extensive); (2) role specialization; (3) institutional, socio-economic and cultural differentiation and hierarchization; (4) differential access to resources and power; and (5) multi-level functional organization in respect to political, economic, and cultural life. ${ }^{76}$ By the later seventh century and in spite of the dramat-

74 See M.F. Hendy, Studies in the Byzantine monetary economy c. 300-1450 (Cambridge 1985), 164167, 616 - 618; for a broad summary W.E. Kaegi, Byzantium and the early Islamic conquests (Cambridge 1992).

75 J.D. Howard-Johnston, Witnesses to a world crisis: historians and histories of the Middle East in the seventh century (Oxford 2010); idem, 'The rise of Islam and Byzantium's response', in A. Oddy, ed., Coinage and history in the seventh-century Near East (London 2010), 1-9; J.F. Haldon, Byzantium in the seventh century: the transformation of a culture (Cambridge 1997); R.-J. Lilie, Die byzantinische Reaktion auf die Ausbreitung der Araber (Misc. Byz. Monacensia 22. Munich 1976); M. Jankowiak, 'The first Arab siege of Constantinople', Travaux et Mémoires 17 (2013), 237-320.

76 For surveys and overviews of late antiquity and the political, social and economic history of the later Roman state, see the essays in S. Johnson, ed., The Oxford Handbook of Late Antiquity (Oxford and New York 2012); S. Mitchell, A history of the late Roman empire (Oxford 2007). The classic English- 


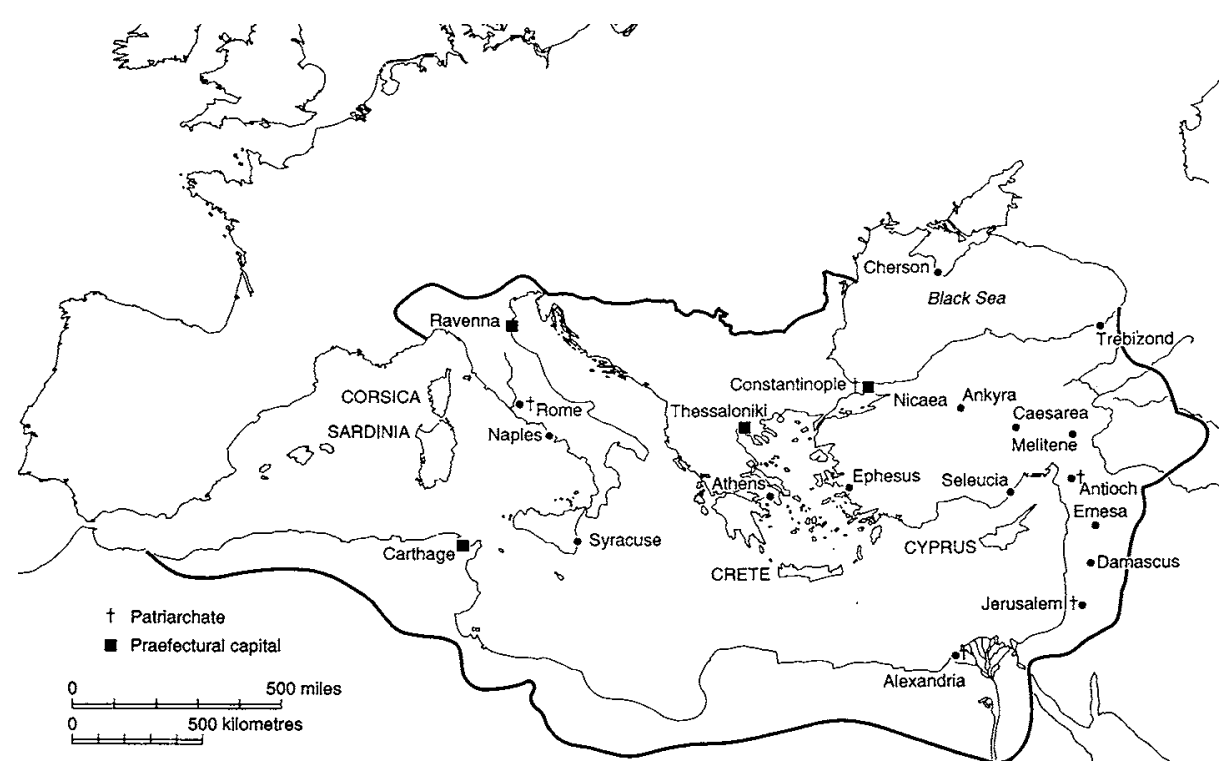

Figure 1a: The eastern Roman empire ca. 565 C.E. with approximate boundaries indicated by the thick black line.

ic shift in its circumstances it can be seen to have retained four out of five of these attributes of complexity. Only in spatial extent was it substantially changed.

Five key factors contributed to the empire's persistence. In the first place, the rump of the eastern Roman state possessed several natural advantages in respect of its strategic geography and the natural frontiers that an invader had to overcome, including strong seasonal weather patterns and especially extremes of temperature and environmental conditions on the central Anatolian plateau. The combination of these aspects enabled the state to organize an effective defence based on minimal central expenditure, led by and relying heavily upon local elites loyal to the centre. ${ }^{77}$ Second, a generally unstable climatic and environmental context actually benefited the empire by fortuitously favouring grain production and livestock breeding at just the moment at which these were essential to supporting the military and supplying the capital, Constantinople. ${ }^{78}$ Third, the state maintained an extremely effective cen-

language survey is the three volume A.H.M. Jones, The later Roman empire: a social, economic and administrative survey (Oxford 1964).

77 On the strategic geography of the empire: M. Whittow, 'The strategic geography of the Near East', in idem, The making of Orthodox Byzantium, 600-1025 (London 1996), 15-37; J.F. Haldon, Warfare, state and society in the Byzantine world 550-1204 (London 1999), 34-66; Lilie, Die byzantinische Reaktion auf die Ausbreitung der Araber.

78 See J.F. Haldon, 'Some thoughts on climate change, local environment and grain production in Byzantine northern Anatolia', in A. Izdebski and M. Mulryan, eds., Environment and society in the long Late Antiquity (Late Antique Archaeology 12. Leiden 2019), 200 - 206. 


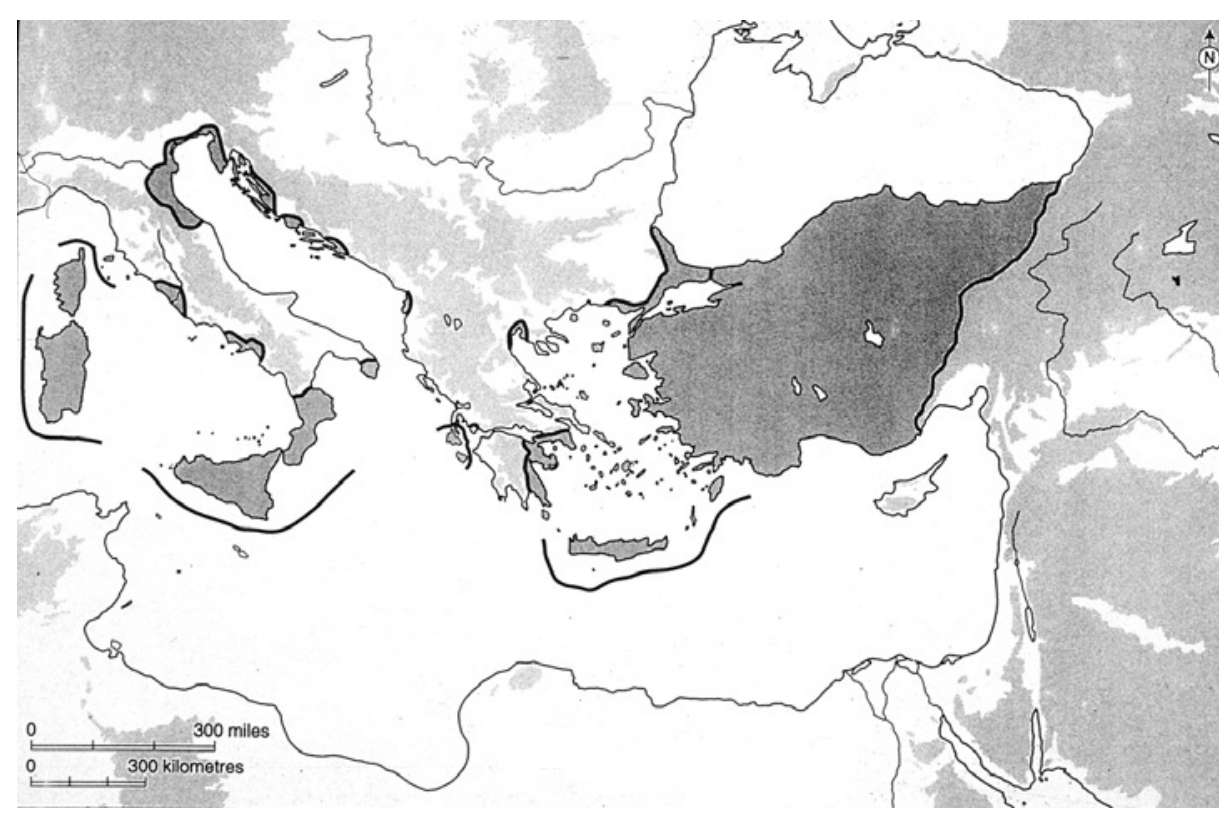

Figure 1b: The eastern Roman (Byzantine) empire ca. 720 C.E. with approximate territorial extent indicated by dark grey shading and thick black lines.

tral administrative apparatus that was able to efficiently extract, distribute and coordinate the consumption of what resources remained to the empire to best advantage. ${ }^{79}$ Fourth, the 'political theology' of the Christian Roman state was deployed consistently to maintain and reinforce imperial authority and legitimacy, thus maintaining a solid grip over provincial elites who managed and administered fiscal and other resources. ${ }^{80}$ This was especially the case with the elites in Anatolia, the south Balkan coastal zones that remained under direct imperial control, but also Sicily and southern Italy. The fifth key aspect relates to the fact that from the middle of the seventh century the system of rank and precedence (and hence social/cultural status and

79 See art. 'Verwaltung, Staatsfinanzen und Steuerwesen', in Byzanz - Handbuch zu Kultur und Geschichte (Neuer Pauly, Supplement 10. Mainz 2017), 285-296; and 'Staatshaushalt', ibid., 501-511; W. Brandes, Finanzverwaltung in Krisenzeiten. Untersuchungen zur byzantinischen Administration im 6.9. Jahrhundert (Frankfurt am Main 2002); J.F. Haldon, 'Bureaucracies, elites and clans: the case of Byzantium ca 500-1100', in P. Crooks and T. Parsons, eds., Empires and bureaucracy in world history: from late Antiquity to the twentieth century (Cambridge 2016), 147-169.

80 E.g. W. Brandes, 'Taufe und soziale/politische Inklusion und Exklusion in Byzanz', Rechtsgeschichte/ Legal history 21 (2013) 75-88; P. Magdalino, 'Orthodoxy and Byzantine cultural identity', in A. Rigo and P. Ermilov, eds., Orthodoxy and heresy in Byzantium. The definition and notion of Orthodoxy and some other studies on the heresies and the non-Christian religions (Quaderni di Nea Rome 4. Rome 2010) 21-46; Av. Cameron, 'Enforcing orthodoxy in Byzantium', Studies in Church History 43 (= K. Cooper and J. Gregory, eds., Discipline and diversity. Woodbridge 2007) 1-24. 
peer-recognition) became increasingly focused on the imperial court and on personal connection with the ruler; an influx of dependent elites from non-traditional origins facilitated maximum state control. ${ }^{81}$ In Anatolia this permitted constant re-occupation of sites/key points, roads, and other resources captured by the invaders. ${ }^{82}$

This high level of infrastructural and ideological cohesion and identity, combined with the other factors noted already, meant in effect that system identity survived (and was reinforced) and systemic complexity was retained at all levels, except at that of spatial extent: here, a significant 'simplification' (i.e. a reduction or loss) took place in terms of territorial control. Yet this substantial loss of territory contributed to sustainability and resilience by substantially reducing the state's marginal maintenance costs and permitting a high degree of direct central control, with the result that the state could survive as a spatially and economically attenuated systemic complex. The adaptive capacity of the East Roman state is thus articulated through the geographical and geopolitical advantages it enjoyed, the incidental benefits of (unperceived) climatic/environmental factors, its substantial organizational advantages, the fact that the government at Constantinople was able to maintain a relatively tight control over the Anatolian, Balkan, and Italian/Sicilian elites, and the fact that the empire possessed a degree of ideological cohesion and identity that often, if not always, transcended class and regional divisions. ${ }^{83}$ Last, but by no means least, its major political/ideological enemy, the Umayyad Caliphate, had to contend in its own domain with both high levels of regionalisation and a dispersal of resources, as well as its own internal conflicts. ${ }^{84}$ The only context in which one might talk of 'collapse' here is in respect of the spatial extent of the empire and, as a consequence, in a reduction in state income. But as noted above, this was managed effectively through the compensatory organizational changes that were introduced. But we should be careful to limit the term to this single aspect, and at the same time to note that it was precisely this reduction that contributed in a major way to the survival of this complex early medieval state formation. Contemporary commentators, fully aware of the former glories and extent of the empire, remained nevertheless entirely convinced of their empire's continuing survival and indeed cultural superiority. For them, the crisis had been overcome because of its inherent cultural, ideological and organizational/military superiority. This case offers, indeed, a good example of a geo-strategic shrinkage that in effect aided stabilisation, resilience and recovery, as

81 L. Brubaker and J.F. Haldon, Byzantium in the iconoclast era, 680-850. A history (Cambridge 2011), 573-598.

82 Detailed discussion and analysis of these key points in J.F. Haldon, The empire that would not die: the paradox of East Roman survival 640-740 (Cambridge, Mass. 2016), esp. 159-282.

83 On adaptive capacity see the discussion above, pp. 14-15 with literature in notes 46-50.

84 See, e.g. H. Kennedy, The prophet and the age of the Caliphates. The Islamic Near East from the sixth to the eleventh century (London 1986/Harlow 2004), 90 -98; C.F. Robinson, 'The rise of Islam, 600-705', in C.F. Robinson, ed., New Cambridge History of Islam, 1: The formation of the Islamic world, sixth to eleventh centuries (Cambridge 2010), esp. 202-224. 
well as of the ways in which contemporary and near-contemporary observers and participants understood and explained how their world was changing around them. ${ }^{85}$

\section{The Maya - between collapse and resilience}

The disappearance of the Maya civilization from much of the Yucatán Peninsula of Mexico and most of Belize and Guatemala (Fig. 2) during the ninth and tenth centuries C.E. has attracted the interest of scholars and the general public for decades. ${ }^{86}$ Recent studies have increasingly argued that the Maya disappearance was the result of climate change and in particular episodic droughts over an extended period of time with which Maya society could not cope. A more careful examination of the evidence reveals, however, that this narrative is too simple and that climate change was only one of several interactive factors that contributed to the fate of Maya society.

Maya society did not encounter an adverse climate in the ninth and tenth centuries for the first time. Complex political systems arose in the interior of the Maya lowlands during the Middle Preclasssic Period (300 B.C.E. - C.E. 150). In the Mirador Basin, located in the Peten of northern Guatemala, local centers reached their cultural apogee in the Late Preclassic Period (300 B.C.E. - C.E. 150), and local palaeoclimate records hint that increased precipitation coincided with cultural development. ${ }^{87}$ But two major drought intervals followed, ${ }^{88}$ and many of these centres were abandoned in the so-called "Preclassic abandonment" (C.E. 150-200).

85 See J.F. Haldon and A. Rosen, 'Introduction: Problems of resilience, adaptation and transformation', in J.F. Haldon, S. White, S. Allcock, D. Bozkurt, M. Cassis, O. Doonan, W.J. Eastwood, H. Elton, D. Fleitmann, A. Izdebski, S. Laparidou, J. Lüterbacher, L. Mordechai, J. Newhard, J. Pickett, J. PreiserKapeller, N. Roberts, A. Sargent, M. Soroush, A. Toreti, S. Wagner, E. Xoplaki and E. Zorita, eds., Society and environment in the East Mediterranean ca 300-1800 CE: resilience, adaptation, transformation (Special Issue, Human Ecology 46/3 (2018), 275-290. For the general political history of the period, see: M.-F. Auzépy, 'State of emergency (700-850)', in J. Shepard, ed. Cambridge History of the Byzantine empire ca. 500 - 1492 (Cambridge 2008), 251-291; T.S. Brown, 'Byzantine Italy (680 - 876)', ibid., 433-464; W.E. Kaegi, 'Confronting Islam: emperors versus caliphs (641-c. 850)’, ibid.: 365-394; A. Louth, 'Byzantium transforming (600-700)', ibid., 221-248. Detailed analyses in J.F. Haldon, Byzantium in the seventh century: the transformation of a culture (Cambridge 1997).

86 See, e.g. J.J. Aimers, 'What Maya collapse? Terminal Classic variation in the Maya lowlands', Journal of Archaeological research 15 (2007), 329-377.

87 J.H. Curtis, D.A. Hodell and M. Brenner, 'Climate variability on the Yucatan Peninsula (Mexico) during the past 3500 years, and implications for Maya cultural evolution', Quaternary Research 46/ 1 (1996), 37-47; M. Medina-Elizalde et al., 'High-resolution speleothem record of precipitation from the Yucatan Peninsula spanning the Maya Preclassic Period', Global and Planetary Change 138 (2016), 93-102; N.P. Dunning, T.P. Beach and S. Luzzadder-Beach, 'Kax and kol: collapse and resilience in lowland Maya civilization', Proceedings of the National Academy of Sciences 109(10) (2012), 3652-3657. 


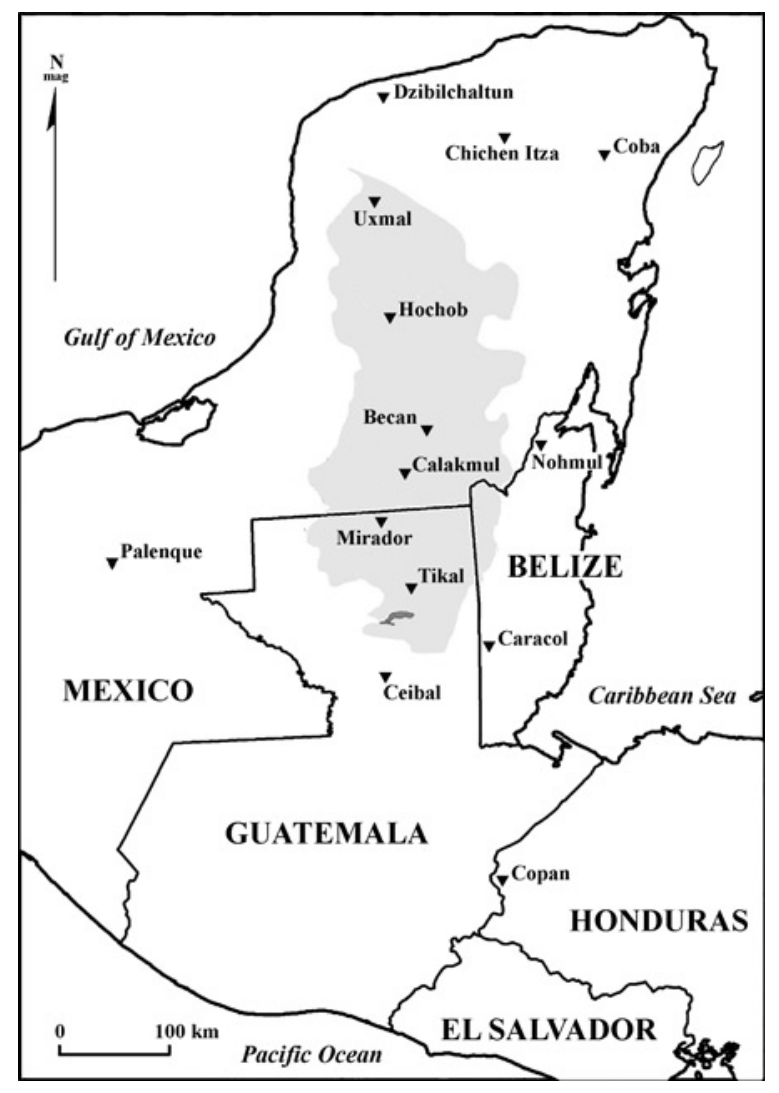

Figure 2: Map of the Maya area highlighting the interior elevated massif of the Yucatán Peninsula

Yet the Preclassic abandonment did not affect the system identity of the culture, and its consequences lasted only a few decades before being reversed. ${ }^{89}$ Maya society demonstrated surprising resilience: the Preclassic abandonment quickly gave way to the major demographic and cultural explosion that characterized the Maya civilization of the Classic Period (C.E 250 -950). The Preclassic abandonment thus did not constitute any sort of Maya collapse according to the criteria outlined above (in particular in terms of system identity, for example), despite temporary demographic change and socio-political and economic disruption.

88 Curtis et al., 'Climate variability on the Yucatan Peninsula'; G.H. Haug et al., 'Climate and the collapse of Maya civilization', Science 299/5613 (2003), 1731-1735; Medina-Elizalde et al., 'High-resolution speleothem record of precipitation from the Yucatan Peninsula' (as in previous note).

89 R.D. Hansen et al., 'Climatic and environmental variability in the rise of Maya civilization: a preliminary perspective from the northern Peten', Ancient Mesoamerica. 13 (2002), 273-297; following Cumming and Peterson, 'Unifying research on social-ecological resilience and collapse'. 
As new states appeared during the Classic Period, the expansion of Maya populations to locations without relatively easy access to perennial water sources made the use and spread of new technologies necessary. ${ }^{90}$ For example, the Maya increasingly used seasonal wetlands, ${ }^{91}$ constructed reservoirs to efficiently capture, channel, and store rainfall within cities, ${ }^{92}$ and built extensive terraces to prevent soil erosion and to enhance soil moisture for agricultural production. ${ }^{93}$

The Maya socio-political system was similarly formalized and expanded during the Classic Period, largely focusing on political and religious rulers known as divine lords, K'uhul Ajaw. Autonomous or semiautonomous communities under such lords proliferated, while population growth and density reached their historical peaks in the Late Classic Period..$^{94}$

Yet, the Classic Maya socio-political system ended abruptly during the Terminal Classic Period (C.E. 780 -950), another transformative era during which major centers were abandoned and the population severely decreased throughout much of the lowlands. Initial signs of political disintegration and demographic change occurred C.E. 760 in the southeastern Petén of Guatemala amidst indications of endemic warfare, but the eventual collapse was protracted and varied by city and region. ${ }^{95}$

90 A.S.Z. Chase and R. Cesaretti, 'Diversity in Ancient Maya water management strategies and landscapes at Caracol, Belize and Tikal, Guatemala', WIREs Water 6 (2019), doi:10.1002/wat2.1332; L.J. Lucero, J.D. Gunn, and V.L. Scarborough, 'Climate change and Classic Maya water management', Water 3(2) (2011), 479-494; D.Z. Chase and A.F. Chase, 'Caracol, Belize and changing perceptions of ancient Maya society', Journal of Archaeological Research 25(3) (2017), 185-249.

91 Dunning et al., 'Kax and kol: collapse and resilience in lowland Maya civilization'; N.P. Dunning et al., 'Geoarchaeological investigations in Mesoamerican move into the 21st century: a Review', Geoarchaeology: an International Journal 30 (2015), 167-199.

92 V.L. Scarborough, N.P. Dunning, K.B. Tankersley, C. Carr, E. Weaber, L. Graziosos, B. Lane, J.G. Jones, P. Buttles and F. Valdez, 'Water and sustainable land use at the ancient tropical city of Tikal, Guatemala', Proceedings of the National Academy of Sciences of the USA 109 (2012), 1240812413; A.S.Z. Chase, 'Beyond elite control: residential reservoirs at Caracol, Belize', WIREs Water 3 (2016), 885-897.

93 E.g. A.S.Z. Chase and J.F. Weishampel, 'Using LiDAR and GIS to investigate water and soil management in the agricultural terracing at Caracol, Belize', Advances in Archaeological Practice 4 (2016), 357-370; A.F Chase and D.Z. Chase, 'Scale and intensity in Classic Period Maya agriculture: terracing and settlement at the 'Garden City’ of Caracol, Belize’, Culture and Agriculture 20(2) (1998), 60 - 77. 94 Between C.E. 600 - 750 the lowland Maya area supported a population of minimally three million people and high settlement density. B.L. Turner, 'Population reconstruction of the Central Maya Lowlands: 1000 B.C. to A.D. 1500’, in T.P. Culbert and D.S. Rice, eds., Precolumbian population history in the Maya Lowlands (Albuquerque 1990), 301-324. An even higher estimate of 7 to 11 million is provided by: M.A. Canuto, F. Estrada-Belli, T.G. Garrison, S.D. Houston, M.J. Acuna, M. Kovac, D. Marken, P. Nondedeo, L. Auld-Thomas, C. Castanet, D. Chatelain, C.R. Chiriboga, T. Drapela, T. Lieskovsky, A. Tokovinine, A. Velasquez, J.C. Fernandez-Diaz and R. Shresha, 'Ancient lowland Maya complexity as revealed by airborne laser scanning of northern Guatemala’, Science 361 (2018), 1355, eaau0137 (2018). doi: 10.1126/science.aau0137.

95 A. Demarest, 'After the maelstrom: collapse of the Classic Maya kingdoms and the Terminal Classic in Western Peten', in A.A. Demarest, P.M. Rice and D.S. Rice, eds., The Terminal Classic in the Maya 
However, by the early tenth century, almost all of the most powerful cities and highly populated polities in the central Maya lowlands were abandoned. ${ }^{96}$ In two centuries, the Maya had largely disappeared from the immense non-coastal lowlands from the Puuc Hills in the northern part of the Yucatán Peninsula to the highlands of Guatemala in the south.

Palaeoclimate records suggest that, similar to the late Preclassic abandonment, the disintegration of Classic Period Maya civilization (C.E. 780-950) coincided with an interval of reduced precipitation in the Maya lowlands. ${ }^{97}$ This time, however, there was no wide-scale reoccupation and political re-structuring in the interior massif of the Maya lowlands, although areas dependent on water storage systems as opposed to permanent groundwater seem to have been the hardest hit.

Classic Period Maya had adapted to, and flourished under, a highly variable hydroclimate. Their techno-managerial strategies had significantly improved over the course of the Classic Period, buffering Maya society against frequent precipitation reductions and droughts. These technological advances and prolonged cultural adaptations helped their societies to persist and grow in a drought-prone environment and imply that the decreased precipitation was not the only cause of the political fragmentation, demographic decline, and disappearance of the Classic Maya civilization from the elevated interior lowlands (see Fig. 2). Instead, both human-induced landscapes and social conditions during the Late Classic Period had changed, reach-

Lowlands: collapse, transition, and transformation (Boulder, Co. 2004), 102-124; T. Okoshi, A.F. Chase, P. Nondedeo and M.C. Arnauld, eds., Rupture and transformation of Maya kingship: from Classic to Postclassic times (Gainesville 2021).

96 The last inscriptions and long-count dates from formerly powerful states cluster around C.E. 889; the last dates recorded at Tikal, Caracol, and Calakmul are, respectively, C.E. 869, C.E. 884, and C.E. 899. Some researchers have argued that this last clustering of dates was associated with a Maya belief system in cyclical time that saw inevitable change and collapse as occurring at this point in time: see, e.g., D.E. Puleston, 'An epistemological pathology and the collapse, or why the Maya kept the short count', in N. Hammond and G.R. Willey, eds., Maya Archaeology and Ethnohistory (Austin 1979), $63-71$.

97 N.P. Evans, T.K. Bauska, F. Gázquez-Sánchez, M. Brenner, J.H. Curtis and D.A. Hodell, 'Quantification of drought during the collapse of the classic Maya civilization', Science 361 (2018), 498-501; W. C. Carleton, D. Campbell and M. Collard, 'Increasing temperature exacerbated Classic Maya conflict over the long term', Quaternary Science Reviews 163 (2017), 209-218; J.H. Curtis et al., 'A multi-proxy study of Holocene environmental change in the Maya lowlands of Peten, Guatemala', Journal of Paleolimnology 19/2 (1998), 139-159; Curtis et al., 'Climate variability on the Yucatan Peninsula'; P.M.J. Douglas et al., 'Drought, agricultural adaptation, and sociopolitical collapse in the Maya Lowlands', Proceedings of the National Academy of Sciences 112/18 (2015), 5607-5612; D.A. Hodell, J.H. Curtis and M. Brenner, 'Possible role of climate in the collapse of Classic Maya civilization', Nature 375/6530 (1995), 391-394; D.J. Kennett et al., 'Development and disintegration of Maya political systems in response to climate change', Science, 338/6108 (2012), 788-791; M. Medina-Elizalde et al., 'High resolution stalagmite climate record from the Yucatan Peninsula spanning the Maya terminal classic period', Earth and Planetary Science Letters 298/1-2 (2010), 255-262; M. Medina-Elizalde and E.J. Rohling, 'Collapse of Classic Maya civilization related to modest reduction in precipitation', Science 335/6071 (2012), 956-959. 
ing a tipping point in human-environment relationships. ${ }^{98}$ Part of the tipping point was that Maya societies had become both more reliant on established agro-technologies and more economically interdependent throughout the Classic Period - a prime exemplification of the impacts of the overly-complex societal structure outlined by Tainter and of the 'rigidity trap' described by Gunderson and Holling. ${ }^{99}$ While cause-effect relationships are difficult to disentangle, the Terminal Classic Period was characterized by political fragmentation within and among polities combined with shifting alliances and endemic warfare set among changing trade routes that circumvented, rather than crossed, the Yucatán Peninsula; all this points at heightened competition for scarce resources, socio-economic degradation, and the loss of credibility in the leadership expected to maintain the system. ${ }^{100}$ These factors, together with the prolonged and intensive drought and high upkeep costs related to the built landscape, likely made maintenance of the production system difficult, especially given the increased pressures on the land. ${ }^{101}$

In spite of the more favorable climate and soil conditions that returned soon after the breakdown of Classic Period polities, however, the Maya political structures and economies were not resurrected. ${ }^{102}$ Unlike the Preclassic-Classic transformation

98 A.F. Chase and V.L. Scarborough, The resilience and vulnerability of ancient landscapes: transforming Maya archaeology through IHOPE. AP3 A Paper 24 (American Anthropological Association. Arlington 2014); J.D. Gunn et al., 'A distribution analysis of the Central Maya Lowlands ecoinformation network: its rises, falls, and changes', Ecology and Society 22(1) (2017), no. 20 https://www.doi.org/10. 5751/ES-08931-220120; Haug et al., 'Climate and the collapse of Maya civilization'; S.C. Heckbert et al., 'Growing the Maya socio-ecological system from the bottom up', in C. Isendahl and D. Stump, eds., Handbook of historical ecology and applied archaeology (Oxford 2016); L.C. Peterson and G.H. Haug, 'Climate and the collapse of Maya civilization', American Scientist 93 (2005), 322-329; J.W.G. Lowe, The dynamics of apocalypse: a systems simulation of the classic Maya collapse (Albuquerque 1965); B.L. Turner and J.A. Sabloff, 'Classic Period collapse of the Central Maya Lowlands: insights about human-environment relationships for sustainability', Proceedings of the National Academy of Sciences of the USA 109(35) (2012), 13908-13914.

99 See above; also Carpenter and Brock, 'Adaptive capacity and traps'; D.Z. Chase and A.F. Chase, 'Path dependency in the rise and denouement of a Classic Maya city: the case of Caracol, Belize', in A.F. Chase and V.L. Scarborough, eds., The resilience and vulnerability of ancient landscapes (2014), 142-154; and A.F. Chase, M.C. Arnauld, D.Z. Chase, P. Nondedeo and T. Okoshi, 'The rupture and transformation of Maya kingship: an epilogue' in T. Okoshi et al., Maya Kingship: Rupture and Transformation from Classic to Postclassic Times, 349-356.

100 Demarest, 'After the maelstrom'; G. Iannone, The great Maya droughts in cultural context: case studies of resilience and vulnerability (Boulder, Co. 2014); G. Iannone, B.A. Houk, and S.A. Schwake, Ritual, violence, and the fall of the Classic Maya kings (Gainesville 2016); A.F. Chase and P.M. Rice, eds. The lowland Maya Postclassic (Austin 1985).

101 Turner and Sabloff, 'Classic Period collapse of the Central Maya Lowlands'; T. Beach, S. Luzzadder-Beach, S. Krause, T. Guderjan, F. Valdez, J.C. Fernandez-Diaz, S. Eshleman, and C. Doyle, 'Ancient Maya wetland fields revealed under tropical forest canopy from laser scanning and multiproxy evidence', Proceedings of the National Academy of Sciences 116, no. 43 (2019), 21469-21477.

102 A.D. Mueller et al., 'Recovery of the forest ecosystem in the tropical lowlands of northern Guatemala after disintegration of Classic Maya polities', Geology 38(6) (2010), 523-526. 
which saw cultural continuity, new religious beliefs and ideologies developed in the Maya area in the Terminal Classic Period, ${ }^{103}$ likely leading to its systemic transformation. For whatever reason, this transformation could not be implemented in the Maya southern lowlands. Although traces of Classic Maya civilization survived within the succeeding Postclassic states and polities, they were substantially differently articulated within these social formations and carried a very different cultural weight. ${ }^{104}$ The Maya lowlands thus remain one of few known heavily occupied, non-island populations in the wider region to have witnessed no recovery after abandonment. ${ }^{105}$

The Maya case reveals that in little more than a century significant shifts in demography, exchange relationships, elite composition, cultural production, the transmission of political power and governance took place. This fundamentally transformed the overall texture and system identity of the Classic Maya civilization and resulted in changes radical enough that they clearly meet the criteria outlined above in respect of systemic collapse, as based on current evidence. ${ }^{106}$ As we noted at the outset, the comparison between this break and the resilience Maya society demonstrated during the earlier Preclassic abandonment serves both as a reminder against oversimplifying cases of historical collapse, as well as of the need to interrogate each case on its own merits and to examine the causal interrelationships that generated each set of outcomes.

\section{Conclusion}

There are many ways to approach the nature of both long- and short-term historical transformation that permit us to understand both aspects. We might bear in mind Renfrew's idea of a 'multiplier effect', for example, a process observed in archaeological data through which smaller and originally unconnected changes at different lev-

103 E. g. A. Chase, 'Troubled times: the archaeology and iconography of the Terminal Classic southern lowland Maya', in M.G. Robertson and V.M. Fields, eds., Fifth Palenque Round Table, 1983, VII (San Francisco 1985), 103-114; W.M. Ringle, T. Gallareta-Negron, and G.J. Bey, 'The return of Quetzalcoatl: evidence for the spread of a world religion during the Epiclassic Period', Ancient Mesoamerica 9 (1998), 183-232.

104 D.Z. Chase and A.F. Chase, 'Hermeneutics, transitions, and transformations in Classic to Postclassic Maya society', in A. Demarest, P. Rice and D. Rice., eds., The Terminal Classic in the Maya lowlands: collapse, transition, and transformation (Boulder, Co. 2004), 12-27; D.Z. Chase and A.F. Chase, 'The rupture of Classic Maya divine kingship from the perspective of Postclassic archaeology, iconography, and ethnohistory', in T. Okoshi et al., Maya Kingship: Rupture and Transformation from Classic to Postclassic Times, 291-310.

105 B.L. Turner, 'The Ancient Maya: sustainability and collapse?', in J.L. Cardona, ed., Routledge Handbook of the History of Sustainability (Oxford 2018), 57-68.

106 D.Z. Chase and A.F. Chase, 'Framing the Maya collapse: continuity, discontinuity, method, and practice in the Classic to Postclassic southern Maya lowlands', in G.M. Schwartz and J.J. Nichols, eds., After collapse: the regeneration of complex societies (Tucson 2006), 168-187. 
els of a social system occur at an increasingly rapid rate, eventually coalescing and generating an impact sufficient to stimulate sudden transformative change across a whole societal system. The cumulative outcomes of such sudden transformation might reasonably be described under the rubric of collapse - again, because qualitative and systemic change results in a loss of system identity over the short term. But it is essential to consider the longer-term build-up that generated such tipping points, something to which a resilience-theory approach can also contribute. ${ }^{107}$ Such transformations within complex systems can be described in terms of 'punctuated equilibria', where change is seen less in terms of gradual, continuous societal evolution and more in terms of extended periods of relatively stable relations (stasis) punctuated by short periods of rapid non-linear change, generating in turn a new equilibrium. These ideas are similar to Kuhn's approach to 'paradigm shifts' in the way knowledge is generated and develops as well as to discussions of the spacetime relationship in geomorphology, in which a long-term 'dynamic equilibrium' is moderated by a range of time-determined impacts that punctuate the longer-term relationships. ${ }^{108}$ By the same token, we can approach such change from the perspective of fragility - to what extent do sudden transformations reflect systemically relatively fragile socio-political structures, how and why did they survive, as many did, as long as they did, and where were their major systemic vulnerabilities? ${ }^{109}$

But the key point is that historical social-ecological transformations have more often than not been adaptations or re-organizations - partial, disjointed, and entailing medium-term refocusing of resources (people, materials, land) within reconfigured political-economic relationships. Structurally normative elements contributing to resilience or sustainability at different levels are an aspect of all complex systems. Gradual shifts in system identity, evolving unevenly across different segments of a society, are the norm, rather than the all-encompassing catastrophic breakdowns and loss of system identity most commonly understood by the term 'collapse'. Presenting past systemic changes as dramatic and irresistible events resulting inevitably in collapse does not help support efforts to develop more sustainable policies in the

107 See C. Renfrew, The emergence of civilisation: the Cyclades and the Aegean in the Third Millennium B.C. (London 1972); and Haldon and Rosen, 'Problems of resilience, adaptation and transformation'.

108 N. Eldredge and S.J. Gould, 'Punctuated equilibria: an alternative to phyletic gradualism', in Models in paleobiology, ed. T.J.M. Schopf (San Francisco 1972), 82-115; S.J. Gould, The structure of evolutionary theory (Cambridge, Mass. and London 2002); also S.A. Schumm and R.W. Lichty, 'Time, space and causality in geomorphology', American Journal of Science 263 (February 1965), 110 - 119. For the application of such approaches to ancient Egypt, for example, see M. Barta, 'Status, race and the mechanism of change in a complex civilisation: Ancient Egypt in between 2900 and 2120 BC', in T. Cunningham and J. Driessen, eds., Crisis to collapse: the archaeology of social breakdown (Aegis 11. Louvain 2016), 277-293.

109 See the important introductory comments and the contributions in N. Yoffee, The Evolution of Fragility: Setting the Terms (Cambridge 2019). 
modern world and, indeed, is probably ineffective in encouraging shifts in behavior and policy. ${ }^{110}$

We end with a series of questions. When is using the term 'collapse', which is both retroactive and subjective, appropriate to the historical contexts to which it is so frequently applied? Does it really accurately describe or account for the fragmented, regionalized, and socially-differentiated processes that the evidence almost invariably indicates, or for the variable degrees of societal and infrastructural resilience that the historical and archaeological records reveal? Does it do justice to the pace and duration of change? And does it properly account for the perceptions of change that the people in question may in fact have had? Or does it, on the contrary, serve in the main to dramatize long-past events, to push human actors into the background and deprive them of the power to influence the world they inhabited, to mystify and to 'orientalize' the past, and to dangerously over-simplify complex causal relationships?

110 Strunz et al., 'Leaving the “sustainability or collapse” narrative behind' (cited n. 5 above), 1725. 